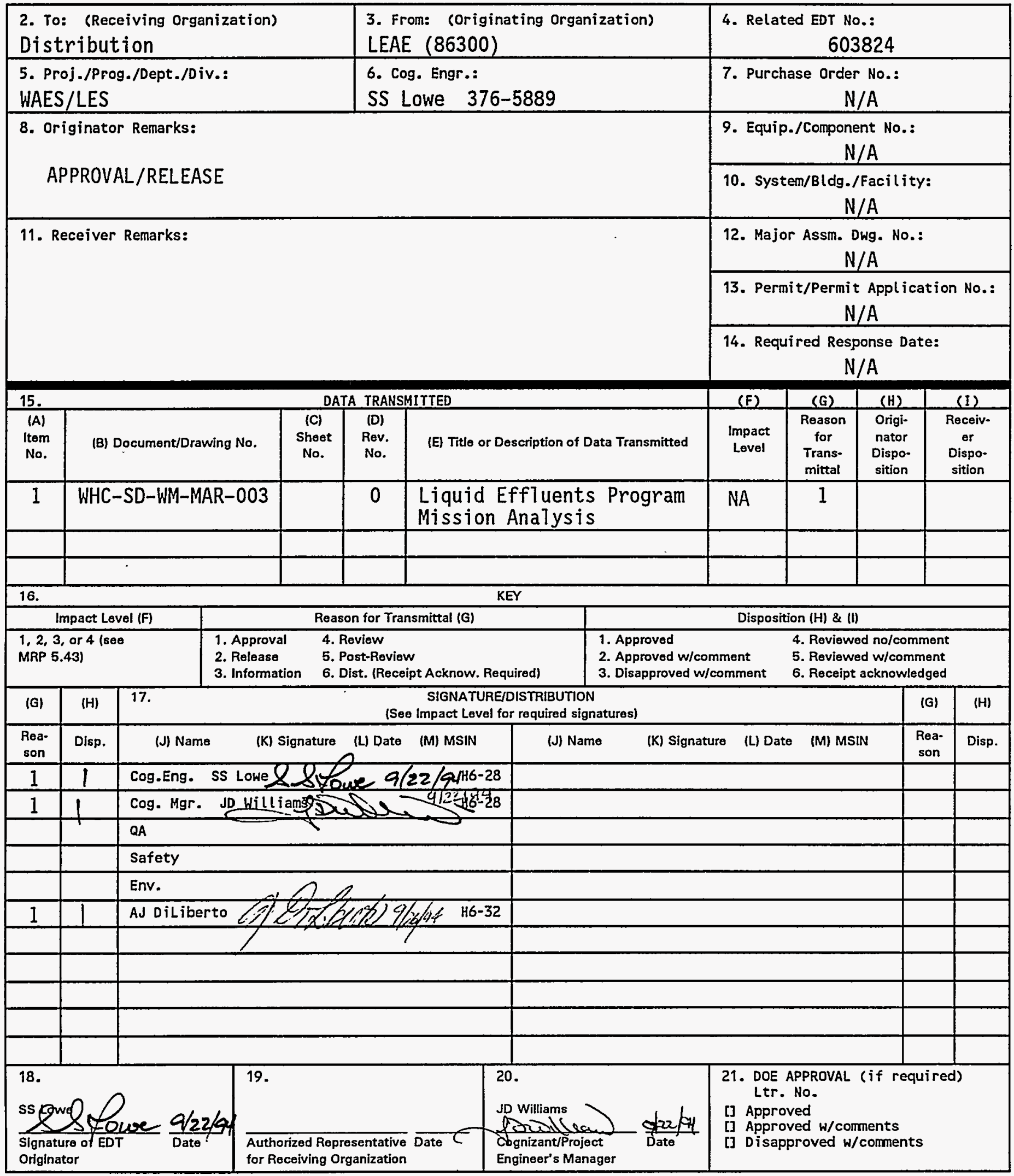




\section{DISCLAIMER}

Portions of this document may be illegible in electronic image products. Images are produced from the best available original document. 


\section{RELEASE AUTHORIZATION}

Document Number: $\quad$ WHC-SD-WM-MAR-003, REV. 0

Document Title: $\quad$ Liquid Effluents Program Mission Analysis

Release Date: $\quad 9 / 27 / 94$

***************

This document was reviewed following the procedures described in WHC-CM-3-4 and is:

APPROVED FOR PUBLIC RELEASE

***************

WHC Information Release Administration Specialist:

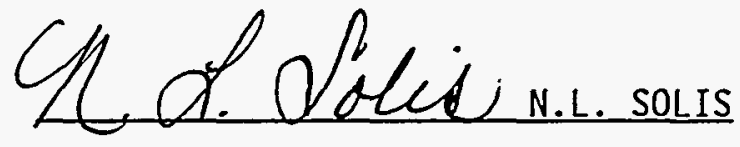

(Signature)

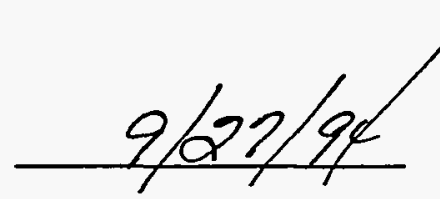

(Date) 


\begin{tabular}{|l|l|c|}
\hline $\begin{array}{l}\text { 2. Title } \\
\text { LIQUID EFFLUENTS PROGRAM MISSION ANALYSIS }\end{array}$ & $\begin{array}{l}\text { 3. Number } \\
\text { WHC-SD-HM-MAR-003 }\end{array}$ & $\begin{array}{c}\text { 4. Rev No. } \\
0\end{array}$ \\
\hline $\begin{array}{l}\text { 5. Key Words } \\
\text { Liquid effluent, treatment, disposal, mission } \\
\text { analysis, functions and requirements, systems } \\
\text { engineering, wastewater }\end{array}$ & $\begin{array}{l}\text { 6. Author } \\
\text { Name: SS Lowe }\end{array}$ \\
& $\begin{array}{l}\text { Signature } \\
\text { organization/Charge code } 86300 / A 2 C A P\end{array}$ \\
\hline
\end{tabular}

\section{Abstract}

Systems engineering is being used to identify work to cleanup the Hanford Site. Mission analysis is the first step in the systems engineering process. The results of a mission analysis conducted for the Liquid Effluents Program are described herein. This report identifies the initial conditions and acceptable final conditions, defines the programmatic and physical interfaces and sources of constraints, estimates the resources to carry out the mission, and establishes measures of success.

\section{APPROVED FOR PUELIC RELEASE 9/27/94 D.solic}

8. PURPOSE WN USE OF DOCUMENT This Wcument was prepted for use within th U.S. Department of Energy an its contracsors. It is to be used inly to pegorm, direct, or integrite work under U.S. Departint of Enefy contracts. This docum ist is not approved for public re ease yífil reviewed.

PATENT STATUS This document copy, sine is transmitted in advance of patith clearance, is made avaj able confidence solely for use jor per ormance of work hder com racts with the U.S. Depament of E ergy. This docurnt is not to pe published nor its cont ints otherwis disseminated $A$ used for purpes other than specif ed above before patent appr val for such releas, or use has been secured, upon request, from re Patent Counsel, U.S. Department of Nergy field office, Richland, WA.

DISCLAIMER - This report was prepared as an account of work sponsored by an agency of the United States Government. Neither the United States Government nor any agency thereof, nor any of their employees, nor any of their contractors, subcontractors or their employees, makes any warranty, express or implied, or assumes any legal liability or responsibility for the accuracy, completeness, or any third party's use or the results of such use of any information, apparatus, product, or process disclosed, or represents that its use would not infringe privately owned rights. Reference herein to any specific comercial product, process, or service by trade name, trademark, manufacturer, or otherwise, does not necessarily constitute or imply its endorsement, recommendation, or favoring by the United States Government or any agency thereof or its contractors or subcontractors. The views and opinions of authors expressed herein do not necessarily state or reflect those of the United States Government or any agency thereof.

9. Impact Level NA
10. RELEASE STAMP

OFFICIAL RELEASE BY WHC DATE SEP 271994

35 station 21 
WHC-SD-WM-MAR-003 Rev. 0

\title{
LIQUID EFFLUENTS PROGRAM \\ MISSION ANALYSIS
}

\author{
Issued by \\ Westinghouse Hanford Company \\ for the \\ U.S. DEPARTMENT OF ENERGY, RICHLAND FIELD OFFICE \\ RICHLAND, WASHINGTON
}

September 1994 
WHC-SD-WM-MAR-003 Rev. 0

\section{CONTENTS}

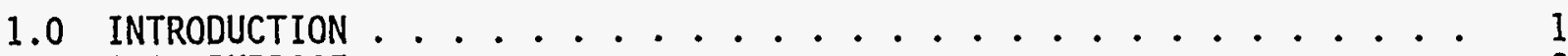

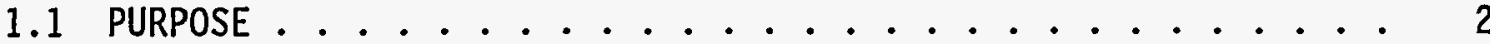

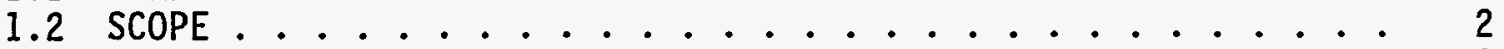

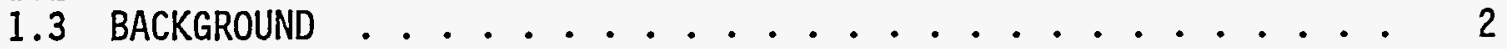

2.0 MISSION ANALYSIS RESULTS ................ 5

2.1 MISSION STATEMENT . . . . . . . . . . . . . 5

2.2 MISSION OBJECTIVES ................ 5

2.3 INITIAL CONDITIONS ................ 6

2.4 FINAL CONDITIONS ................... 7

2.5. INTERFACES ................ 7

2.6 MISSION RESOURCES . . . . . . . . . . . . . . . 7

2.7 MEASURES OF SUCCESS . . . . . . . . . . . . . 10

2.8 ADDITIONAL INFORMATION NEEDED . . . . . . . . . . . 10

2.9 MISSION FEASIBILITY . . . . . . . . . . . . . . . 10

3.0 REFERENCES . . . . . . . . . . . . . . . 29

\section{APPENDIXES}

A. PROJECTS IN THE LIQUID EFFLUENTS PROGRAM ............ . A-1

B. OTHER LIQUID EFFLUENTS PROJECTS .................... B-1 


\section{LIST OF FIGURES}

1. Physical Interfaces for the Phase I and II Streams . . . . . . . 24

2. Physical Interfaces for Liquid Effluents in the 300 Area . . . . . 25

\section{LIST OF TABLES}

1. Initial Conditions for the Liquid Effluents Program . . . . . . 11

2. Final Conditions for the Liquid Effluents Program . . . . . . . . 15

3. Programmatic Interfaces for the Liquid Effluents Program ...... 16

4. Physical Interfaces for the Liquid Effluents Program . . . . . . 23

5. Measures of Success for the Liquid Effluents Program . . . . . . . 26

6. Additional Information Needed for the Liquid Effluents Program . . . 27

A-1. 200 Area Effluent Treatment Facility, Project C-018H . . . . . . . A A-3

A-2. 200 Area Treated Effluent Disposal Facility, Project W-049H . . . . A-6

A-3. 300 Area Treated Effluent Disposal Facility, Project L-045H . . . A A-9

A-4. Phase II Liquid Effluent Treatment and Disposal, Project $W-252$. . . A-13

A-5. 200 Area Effluent BAT/AKART Implementation, Project W-291 . . . . . A-15

A-6. Liquid Effluent Retention-Facility, Project W-105 ... . . . . . A-17

A-7. 340 Facility Secondary Containment and Leak Detection, Project $\mathrm{W}-302$. . . . . . . . . . . . A-19

A-8. 300 Area Retention Process Sewer Monitoring/Diversion Upgrade, Project $\mathrm{W}-353$. . . . . . . . . . . . A-20

B-1. 300 Area Process Sewer Piping Replacement, Project L-070 . . . . . . B-3

B-2. 307 Basin Maintenance Upgrades, Project $W-345 \ldots \ldots$. . . . B-5

B-3. Richland Treatment P1ant Connection, Project V-784 ... . . . . . B-6

B-4. 300 Area Ash Pond Replacement and Fi7ter Backwash Pond, Project L-059/V-791H-B . . . . . . . . . . . . B-7

B-5. Stormwater Interim Collection and Disposal, Project L-125 . . . . B-8 


\section{ABBREVIATIONS AND ACRONYMS}

\begin{tabular}{|c|c|}
\hline $\begin{array}{l}\text { CWA } \\
\text { DCG } \\
\text { DOE } \\
\text { DOT } \\
\text { DST } \\
\text { ECology } \\
\text { EPA } \\
\text { ERDF } \\
\text { ETF } \\
\text { HPS } \\
\text { ICF Kaiser } \\
\text { LEMIS } \\
\text { LERF } \\
\text { N/A } \\
\text { NEPA } \\
\text { NESHAPS } \\
\text { NPDES } \\
\text { PNL } \\
\text { POTW } \\
\text { PS } \\
\text { PSD } \\
\text { PSE } \\
\text { PUREX } \\
\text { RAEP } \\
\text { RCRA } \\
\text { RL } \\
\text { RLPD }\end{array}$ & $\begin{array}{l}\text { activity data sheets } \\
\text { all known, available, and reasonable methods of treatment } \\
\text { as low as reasonably achievable } \\
\text { best available technology } \\
\text { Boeing Computer Services Richland, Incorporated } \\
\text { Clean Air Act } \\
\text { Comprehensive Environmental Response, Compensation, and Liability } \\
\text { Act } \\
\text { Clean Water Act } \\
\text { derived concentration guide } \\
\text { U.S. Department of Energy } \\
\text { U.S. Department of Transportation } \\
\text { double-shell tank } \\
\text { Washington State Department of Ecology } \\
\text { U.S. Environmental Protection Agency } \\
\text { Environmental Restoration Disposal Facility } \\
\text { Effluent Treatment Facility } \\
\text { Hanford Plant Standards } \\
\text { ICF Kaiser Hanford Company } \\
\text { Liquid Effluent Management Information System } \\
\text { Liquid Effluent Retention Facility } \\
\text { not applicable } \\
\text { National Environmental Policy Act . } \\
\text { National Emissions Standards for Hazardous Air Pollutants } \\
\text { National Pollutant Discharge Elimination System } \\
\text { Pacific Northwest Laboratory } \\
\text { publicly-owned treatment works } \\
\text { process sewer } \\
\text { prevention of significant deterioration } \\
\text { preliminary safety evaluation } \\
\text { Plutonium-Uranium Extraction } \\
\text { Radioactive Air Emissions Program } \\
\text { Resource Conservation and Recovery Act } \\
\text { U.S. Department of Energy, Richland Operations Office } \\
\text { U.S. Department of Energy, Richland Operations Office Policy } \\
\text { Directive } \\
\text { radioactive liquid waste system } \\
\text { retention process sewer } \\
\text { reportable quantity } \\
\text { State-Approved Land Disposal Structure } \\
\text { sampling and analysis plan } \\
\text { State Environmental Policy Act } \\
\text { to be determined } \\
\text { Treated Effluent Disposal Facility } \\
\text { treatment, storage, and disposal } \\
\text { Washington Administrative Code } \\
\text { Westinghouse Hanford Company } \\
\text { Waste Receiving and Packaging }\end{array}$ \\
\hline
\end{tabular}


WHC-SD-WM-MAR-003 Rev. 0

LIQUID EFFLUENTS PROGRAM

MISSION ANALYSIS

\section{EXECUTIVE SUMMARY}

Systems engineering is being used to identify work to cleanup the Hanford Site. The systems engineering process transforms an identified mission need into a set of performance parameters and a preferred system configuration. Mission analysis is the first step in the process. Mission analysis supports early decision-making by clearly defining the program objectives, and evaluating the feasibility and risks associated with achieving those objectives. The results of the mission analysis provide a consistent basis for subsequent systems engineering work.

A mission analysis was performed earlier for the overall Hanford Site. This work was continued by a "capstone" team which developed a top-level functional analysis. Continuing in a top-down manner, systems engineering is now being applied at the program and project levels. A mission analysis was conducted for the Liquid Effluents Program. The results are described herein. This report identifies the initial conditions and acceptable final conditions, defines the programmatic and physical interfaces and sources of constraints, estimates the resources to carry out the mission, and establishes measures of success. The mission analysis reflects current program planning for the Liquid Effluents Program as described in Liquid Effluents FY 1995 Multi-Year Program P1an, WHC-SP-1097 (DiLiberto 1994). 
WHC-SD-WM-MAR-003 Rev. 0:

\subsection{INTRODUCTION}

The U.S. Department of Energy, Richland Operations Office Policy Directive (RLPD) 4900.1, Systems Engineering, requires that systems engineering be used to identify work to cleanup the Hanford Site. Systems engineering is a methodology used for large or complex problems where there is considerable uncertainty and less-than-desired confidence in developing a timely and acceptable solution. The process transforms an identified mission need into a set of performance parameters and a preferred system configuration. Its purpose is to ensure that the product meets the program objectives, satisfies the functional requirements, operates effectively in the intended environment, and demonstrates a level of performance and reliability that justifies the investment.

The Hanford Site Systems Engineering Manual (Jackson 1994), describes the systems engineering process used on the Hanford Site. The approach includes the following steps: mission analysis, functional analysis, requirements identification and allocation, system synthesis and integration, and. alternative evaluation and optimization. Mission analysis provides a clear understanding of the problem and establishes a basis for solution. Functional analysis specifies the functions to be performed and their interdependencies. Requirements identification provides the basis for comparing alternatives and limits the range of acceptable solutions. System synthesis defines the system that meets the requirements and fulfills the mission. Alternative evaluation addresses issues and uncertainties, and assesses their impact. Together these related activities establish the technical baseline.

A mission analysis for cleanup of the Hanford Site was performed by senior executives from Westinghouse Hanford Company (WHC), Pacific Northwest Laboratory (PNL), ICF Kaiser Hanford Company (ICF Kaiser), Boeing Computer Services Richland, Incorporated (BCSR), and Hanford Environmental Health Foundation. The executive mission analysis produced a problem statement, mission statement, and scope statement, and defined the initial state and desired end state. This work was continued by a "capstone" team which developed a top-level functional analysis defining a 71 appropriate functional relationships. The capstone team also specified a top-level set of requirements, constraints, and measures of effectiveness. Subsequent review by the Hanford Site contractors and the U.S. Department of Energy, Richland Operations office (RL), established a consensus as to the mission of the Hanford Site. Results of the top-level mission analysis and functional analysis are provided in Systems Engineering Functions and Requirements for the Hanford Cleanup Mission: First Issue, WHC-EP-0722 (Holmes, 1994).

Continuing in a top-down manner, systems engineering is now being applied at the program and project levels. A mission analysis was conducted for the Liquid Effluents Program; the results are described herein. A functional analysis was next performed, the outcome of which is reported separately. The mission analysis and functional analysis reflect the current program planning for the Liquid Effluents Program as documented in Liquid Effluents FY 1995 Mu7ti-Year Program P7an, WHC-SP-1097 (DiLiberto 1994). 


\subsection{PURPOSE}

Mission analysis is the first step in the systems engineering process. Mission analysis supports early decision-making by clearly defining the program objectives, and evaluating the feasibility and risks associated with achieving those objectives. The results provide a consistent basis for subsequent systems engineering work.

\subsection{SCOPE}

This mission analysis has the following elements:

- Expand and refine the mission statement

- Identify the mission goals or objectives

- Identify the initial conditions and acceptable final output conditions

- Define the boundaries (i.e., programmatic and physical interfaces) and sources of constraints

- Estimate the resources needed to carry out the mission

- Establish criteria to determine the extent to which the problem will be solved (i.e., measures of success)

- Identify additional information needed

- Assess the mission feasibility.

The mission analysis will be updated as the cleanup mission progresses and additional information becomes available.

\subsection{BACKGROUND}

The policy of the U.S. Department of Energy (DOE) is to conduct operations in a safe, cost-effective, and environmentally sound manner and to ensure that discharges of radioactive and nonradioactive materials to the environment meet applicable regulatory requirements and are as low as reasonably achievable (ALARA). The ALARA objective is to reduce both personnel and offsite exposure to the lowest levels consistent with sound, cost-effective operating practice. The policy of the DOE is also that the use of soil columns to treat and retain radionuclides and chemicals in liquid waste streams shall be discontinued at the earliest practicable time in favor of wastewater treatment and minimization.

A plan to stop the discharge of liquid effluents to the soil column is described in Plan and Schedule to Discontinue Disposal of Contaminated Liquids into the Soil Column at the Hanford Site, DOE-065 (RL 1987). This was 1ater updated in Annual Status of the Report of the Plan and Schedule to Discontinue Disposal of Contaminated Liquids into the Soil Column at the Hanford Site, 
WHC-EP-0196-1 (Stordeur and Flyckt 1988), to reflect changes in key assumptions (e.g., placing $\mathrm{N}$ Reactor in cold standby), and provide additional direction and coordination. These documents identified 33 major 1 iquid effluent streams, developed a two-phased prioritization scheme for implementing the plans, established funding mechanisms, and identified projects required to treat and dispose of the liquid effluents. The criteria used to prioritize the streams were based on the effluent disposal criteria contained in applicable DOE Orders and in relevant U.S. Environmental Protection Agency (EPA) and Washington State environmental regulations. The four criteria that identify Phase I Streams are as follows:

- Criterion 1, Radionuclide Concentrations - The effluent contains radionuclides in excess of the derived concentration guide (DCG) values in DOE Order 5400.5, Radiation Protection of the Public and the Environment.

- Criterion 2, Hazardous Waste Characteristics - The effluent exceeds hazardous waste threshold levels in Washington Administrative Code (WAC) 173-303, "Dangerous Waste Regulations."

- Criterion 3, Reportable Quantity or Listed Waste - The effluent release has a potential to contain a reportable quantity (RQ) of a hazardous constituent according to Comprehensive Environmental Response, Compensation, and Liability Act (CERCLA), or has the potential to contain a hazardous waste listed in WAC 173-303.

- Criterion 4, Disposal Facility Life - The facility mission life exceeds the minimum estimated Tife of the disposal site.

Meeting any of the above criteria resulted in a stream being assigned a Phase I priority ranking. The remaining streams were considered lower priority and were scheduled for implementation during Phase II. The strategy for implementing alternative treatment and disposal includes the following:

- Complete detailed characterization of both the Phase I and Phase II Streams for radionuclides and chemical constituents

- Complete "best available technology" (BAT) evaluations"

- Implement BAT treatment and disposal systems for those streams identified as Phase I priority.

The DOE, the EPA, and the Washington State Department of Ecology (Ecology) in May 1989 entered into the Hanford Federal Facility Agreement and

1 The Clean Water Act requires the application of BAT effluent limits to discharges of waste water containing toxic and nonconventional pollutants. A11 waste waters proposed for discharge in the State of Washington must be provided with "al7 known, available, and reasonable methods of treatment" (AKART) in accordance with the Water Pollution Control Act. These terms describe equivalent levels of treatment required for discharge to waters of the United States and the State of Washịngton. 
Consent Order (Tri-Party Agreement) (Ecology et a1. 1994). The purpose of the Tri-Party Agreement is to ensure that the environmental impacts associated with past and present activities at the Hanford Site are thoroughly investigated and appropriate response action is taken as necessary to protect the public health, welfare and the environment. The Tri-Party Agreement provides a framework for permitting treatment, storage, and disposal (TSD) units, and promotes an orderly, effective investigation and cleanup of contamination at the Hanford Site. Included is a joint strategy for reducing and eliminating discharges of 1 iquid effluents, and schedules for implementing technologies for treatment and disposal of those liquid effluents that remain. This joint strategy is reflected as commitment language and milestone dates.

The DOE agreed in December 1991 to adhere to the provisions of the Consent Order No. DE 91NM-177 (Consent Order) (Ecology 1991). The Consent Order 7 ists regulatory milestones for liquid effluent streams at the Hanford Site to comply with the permitting requirements of WAC 173-216, "State Waste Discharge Permit Program," or WAC 173-218, "Underground Injection Control Program" as applicable. Provisions of the Consent Order later became the basis for amendments to the Tri-Party Agreement. While the Consent Order is separate and legally distinct from the Tri-Party Agreement, Ecology intends to maintain consistency with Milestone M-17-00 of the Tri-Party Agreement in implementing the Consent Order.

The Consent Order also identifies several requirements and milestones for Miscellaneous Streams. Miscellaneous Streams are those liquid effluents which discharge from engineered structures to the ground that are not categorized as Phase I or Phase II Streams. A plan to stop the discharge of these Miscellaneous Streams to the soit column is described in Plan and Schedule for Disposition and Regulatory Compliance for Misce 77 aneous Streams, DOE/RL-93-94 (RL 1994a). Included is a strategy for categorizing and evaluating all the streams, and identifying BAT/AKART options. 


\subsection{MISSION ANALYSIS RESULTS}

\subsection{MISSION STATEMENT}

The vision of the Liquid Effluents Program is to provide integrated liquid effluent management to support cleanup of the Hanford Site. The mission as described in the Fiscal Year 1995 Hanford Mission Plan, DOE/RL-102 (RL 1994b), is to manage current and future liquid effluent streams in a safe, responsible, cost-effective, and legally-compliant manner. This is achieved through planning and integration; public and stakeholder interaction; definition of requirements for generators; provision of timely treatment, storage, and disposal capability; and minimization of waste streams where applicable.

\subsection{MISSION. OBJECTIVES}

The Liquid Effluents Program is organized into the following elements: (1) Program Management, (2) 200 Area Liquid Effluent Facilities, (3) 300 Area Liquid Effluent Facilities, and (4) Liquid Effluent Advanced Engineering. Each element has specific objectives which together enable the Liquid Effluents Program to fulfill its mission.

Program Management

- Program Management and Integration. Coordinate, direct, and interface with the customer for activities in the Liquid Effluents Program. Provide administrative support for program documentation, funds management, scheduling, and reporting.

- Liquid Effluent Retention Facility (LERF). Store process condensate from the 242-A Evaporator. Clean out the LERF after its inventory is processed through the 200 Area Effluent Treatment Facility (ETF). (This work scope will be included with the 200 Area ETF Operations beginning in FY 1996.)

200 Area Liquid Effluent Facilities

- 200 Area ETF (Project $\mathrm{C}-018 \mathrm{H}$ ). Treat process condensate from the 242-A Evaporator to the required discharge levels.

- 200 Area Treated Effluent Disposal Facility (TEDF) (Project W-049H). Collect and dispose of 200 Area Phase I Streams and three Phase II Streams meeting BAT/AKART requirements.

- BAT/AKART Implementation (Project $W-291 \mathrm{H}$ ). Implement BAT/AKART at four 200 Area facilities preparatory to discharge to the 200 Area TEDF. 
300 Area Liquid Effluent Facilities

- 300 Area TEDF (Project L-045H). Treat and dispose of 1 iquid effluents from the 300 Area which currently discharge to the 300 Area process trenches.

- 340/307 Facilities. Interim store and monitor liquid effluents generated by the 300 Area 1aboratories operated by PNL, and the retention process sewer.

- 300 Area Process Sewer (Project L-070) and Trenches. Upgrade the 300 Area process sewer piping system. Remove the process trenches from service when the 300 Area TEDF starts up.

\section{Liquid Effluent Advanced Engineering}

- Phase II Streams BAT/AKART (Project W-252). Provide BAT/AKART upgrades and disposal for the remaining Phase II Streams not part of Project $\mathrm{W}-049 \mathrm{H}$.

- 200 Area Advanced Engineering Support. Provide engineering support to the Liquid Effluents Program mission in the 200 Area. Includes integrating future liquid effluent treatment projects with existing facilities and infrastructure, investigating alternate feeds to the 200 Area ETF, other uses of LERF, permitting support, management of the Liquid EffTuent Management Information System (LEMIS), and review of tritium treatment technology.

- 300 Area Advanced Engineering Support. Provide engineering support to the Liquid Effluents Program mission in the 300 Area. Includes investigating alternate feeds to the 300 Area TEDF, and technical input to initiatives to privatize the 300 Area TEDF and connect to the City of Richland publicly-owned treatment works (POTW).

- Miscel1aneous Streams. Assure ful1 regulatory compliance of a11 Tiquid effluent streams not included in the original Phase $I$ and Phase II Streams. Includes the coordination of stream characterization, identification of BAT/AKART, permitting, facility requirements, and regulator approval.

- Interim Compliance. Characterize liquid effluents to support the preparation of WAC 173-216 permit applications. Assess potential impacts to the groundwater from continued interim discharge of Phase I and Phase II Streams.

- Micro Pilot Plant. Perform tests to verify the 200 Area ETF treatment process is effective and that the treated effluent complies with permit requirements.

\subsection{INITIAL CONDITIONS}

Initial conditions for the Liquid Effluents Program are shown in Table 1. These establish the current state of the system on which the mission is to be 
performed. The initial state is described in terms of the system's major topics, or significant system attributes or variables to be considered for treatment by the mission. References are provided where further details may be found. Additional information needed to further define the initial conditions is listed.

Projects have been identified to treat and dispose of many waste streams. A summary of each project within the Liquid Effluents Program, the project status, and related documentation is provided in Appendix A. Projects outside the Liquid Effluents Program are summarized in Appendix B.

\subsection{FINAL CONDITIONS}

Final conditions for the Liquid Effluents Program are shown in Table 2. These establish the end state to be achieved by execution of the mission. The final conditions are described in terms of the end state system's major topics. The end state major topics identify the desired status of significant system attributes or variables that were treated by the mission. Stakeholder values were considered in selecting the end state major topics. Discussion is included which relates the final conditions to the mission objectives. References are provided where further details may be found. Information needed to further define the final conditions is listed.

\subsection{INTERFACES}

There are both programmatic and physical interfaces. Programmatic interfaces originate from agencies which have authority to impose constraints on the mission development process and the end products. Programmatic interfaces are described in Table 3 and the sources of constraints are shown. Physical interfaces are those entities through which the mission receives or transfers information, materials, or energy outside the mission. Physical interfaces are described in Table 4 . Figure 1 shows the physical interfaces for the Phase I and II Streams. Physical interfaces for liquid effluents in the 300 Area are shown in Figure 2.

\subsection{MISSION RESOURCES}

The estimate of the mission resources is based on the mission initial conditions, final conditions, and programmatic and physical interfaces described earlier.

Key WHC Organizations

- Liquid Effluents Program (86100)

- 200 Area Liquid Effluent Facilities (86200)

- 300 Area Liquid Effluent Faci7ities (86700)

- Liquid Effluents Advanced Engineering (86300) 
- RCRA Permitting (88200)

- Air \& Water Permits (88300)

- Regulatory Field Support (88400)

- Regulatory Anatysis (88500)

- NEPA Documentation (88800)

- Chemical Engineering Laboratory (8A400)

- Engineering \& Environmental Demonstration Laboratory (8E140)

- Earth \& Environmental Technical Services (86900)

- Effluent Monitoring (88420)

- Sol id Waste Disposal (87000)

- Waste/Analytical/Environmental Services Safety (31A00)

- Engineering \& Environmental Quality Assurance (38620)

- Environmental Projects (7FB20)

- TWRS Projects Safety (31N40)

- Quality Engineering Construction Projects (38950)

- Liquid Waste Training (135A0)

- Health Physics (33000)

- Site Planning (56300)

- Utilities (54000)

- Procurement \& Materials Management (43000)

- Transportation \& Packaging (84000)

- Systems Engineering (8F000)

- ICF Kaiser (50100)

- $\operatorname{BCSR}(60000)$

Other Key Organizations

- PNL

- Bechtel Hanford 


\section{Ski11 Mix}

- Program management

- Project engineering

- Process engineering

- Plant engineering

- Chemical engineering

- Environmental engineering

- Hydrogeology

- Radiological engineering

- Waste handling, packaging, and shipping (including hazardous materiais)

- Regulatory analysis

- Permitting

- Health physics

- Safety analysis

- Quality assurance

- Procurement

- Construction

- Operations

- Maintenance

- Systems engineering

\section{Required Technologies}

- Methods for characterizing waste streams

- Means for transmitting characterization data to regulators (using the LEMIS)

- Capability to treat contaminants

- Systems to verify the adequacy of treatment

- Environmental monitoring to demonstrate compliance 


\section{Technology Devel opment Tools}

- Micro Pilot Plant for treatability testing and process verification

- Program support by laboratories on the Hanford Site and off-site, and engineering service contracts

\section{Program Cost and Schedule}

The estimated cost and schedule to complete the Liquid Effluents Program mission are provided in Liquid Effluents FY 1995 Multi-Year Program Plan, WHC-SP-1097 (DiLiberto 1994). Manpower requirements are also identified.

\subsection{MEASURES OF SUCCESS}

Stakeholder values and expectations for the Liquid Effluents Program were assessed. Top-level categories of performance measures were identified. Measures of success within these categories were developed relative to the program mission and its objectives. The measures of success are listed in Table 5. When prioritized and further quantified, the measures of success provide a basis on which to evaluate and compare alternatives for treating and disposing of liquid effluents.

\subsection{ADDITIONAL INFORMATION NEEDED}

Additional information has been identified which is needed to execute the mission and satisfy the goals and objectives. This missing information is generally related to (1) availability of resources, (2) completeness or correctness of source documents, (3) applicability of constraints or requirements, or (4) consistency of stakeholder values. A summary of the information needed is provided in Table 6.

\subsection{MISSION FEASIBILITY}

The Liquid Effluents Program is relatively mature compared to other programs on the Hanford Site. Funding for most projects has been established and the treatment technology is based on sound engineering fundamentals. However, startup of the 200 Area ETF and 300 Area TEDF may be postponed due to construction delays and permitting issues. Continued discussion with Ecology should resolve the permitting issues. Uncertainty also exists in the waste streams potentially needing treatment in the future. As the overall cleanup mission of the Hanford Site evolves, these will be better defined. 
Table 1. Initial Conditions for the Liquid Effluents Program.

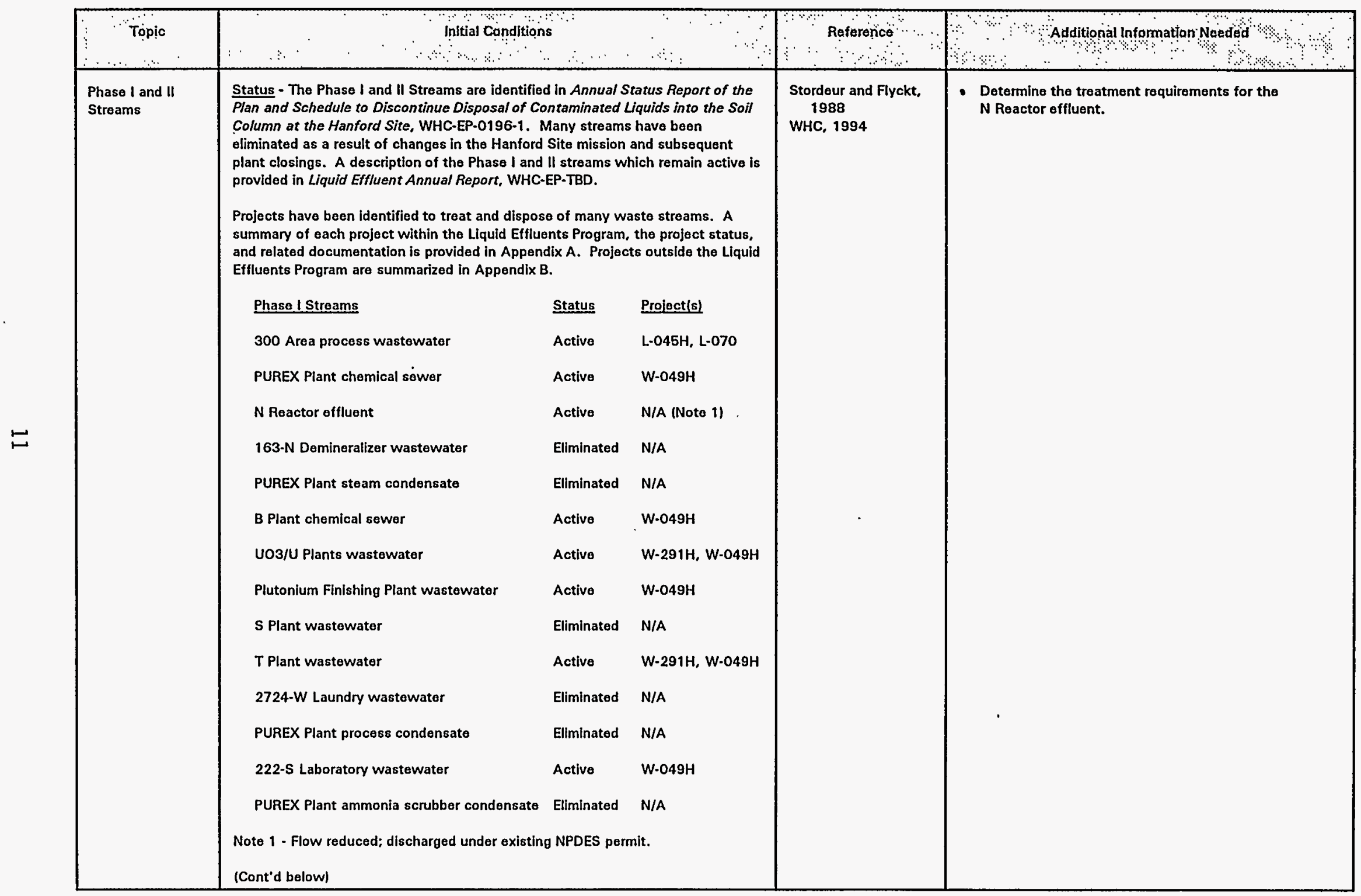


Table 1. Initial Conditions for the Liquid Effluents Program (cont'd).

\begin{tabular}{|c|c|c|c|c|c|}
\hline Topic & Inftial Canditior & & & Raferençe & $\begin{array}{l}\text { Additional Informatton Needed } \\
\vdots\end{array}$ \\
\hline $\begin{array}{l}\text { Phase I and II } \\
\text { Streams (cont'd) }\end{array}$ & $\begin{array}{l}\text { (Cont'd above) } \\
\text { Phase I Streams } \\
\text { 242-A Evaporator process condensate } \\
\text { B Plant steam condensate } \\
\text { B Plant process condensate } \\
\text { 2101-M Laboratory wastowater } \\
\text { U03 Plant process condensate } \\
\text { Phase Il Streams } \\
\text { PUREX Plant cooling water } \\
\text { 242-A Evaporator cooling water } \\
\text { 8 Plant cooling water } \\
\text { 241-A Tank Farm cooling water } \\
\text { 284-E Powerhouse cooling water } \\
\text { 244-AR Vault cooling water } \\
\text { 284-W Powerhouse cooling water } \\
\text { 400 Area secondary coolling water } \\
\text { 242-A Evaporator steam condensate } \\
\text { 242-S Evaporator steam condensate } \\
\text { 241-AY/AZ Tank Farms steam condensate } \\
\text { 209-E Laboratory reflector water } \\
\text { T Plant Laboratory wastewater } \\
\text { 183-D Filter backwash wastewater } \\
\text { Note 2- WAC 173-216 permit application subm }\end{array}$ & $\begin{array}{l}\text { Status } \\
\text { Active } \\
\text { Eliminated } \\
\text { Eliminated } \\
\text { Active } \\
\text { Active } \\
\text { Status } \\
\text { Eliminated } \\
\text { Active } \\
\text { Active } \\
\text { Active } \\
\text { Active } \\
\text { Active } \\
\text { Active } \\
\text { Active } \\
\text { Active } \\
\text { Active } \\
\text { Eliminated } \\
\text { Eliminated } \\
\text { Active } \\
\text { Eliminated } \\
\text { itted. }\end{array}$ & $\begin{array}{l}\text { Projact(s) } \\
\text { W-105, C-018H } \\
\text { N/A } \\
\text { N/A } \\
\text { W-291H, W-049H } \\
\text { W-291H, W-049H } \\
\text { Project(s) } \\
\text { N/A } \\
\text { W-252 } \\
\text { W-252 } \\
\text { W-252 } \\
\text { W-252 } \\
\text { W-252 } \\
\text { W-291H, W-049H } \\
\text { N/A (Note 2) } \\
\text { W-252 } \\
\text { W-049H } \\
\text { N/A } \\
\text { N/A } \\
\text { W-291H, W-049H } \\
\text { N/A } \\
\end{array}$ & & ${ }^{\circ}$ \\
\hline
\end{tabular}


Table 1. Initial Conditions for the Liquid Effluents Program (cont'd).

\begin{tabular}{|c|c|c|c|}
\hline Topic : & 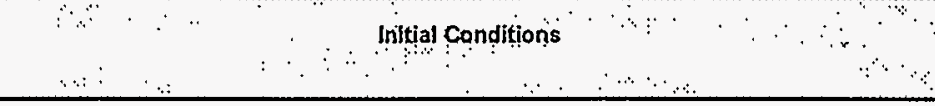 & $\begin{array}{cccc} & \text { Referenco } \\
\end{array}$ & Additional Informatton Needed \\
\hline $\begin{array}{l}\text { Phase I and II } \\
\text { Streams (cont'd) }\end{array}$ & $\begin{array}{l}\text { Characterization - Sampling and analysis plans (SAPs) for the active Phase I and II } \\
\text { Streams were developed as part of the Consent Order. The objectives of the } \\
\text { SAPs are to provide a representative sampling of wastes discharged to the soil } \\
\text { column, account for variations in volumes and contaminant concentrations due to } \\
\text { operational practices, and consider all of the parameters known or suspected to } \\
\text { be associated with each stream such as the influence of operating practices, raw } \\
\text { water characteristics, and process knowledge. The SAPs are referenced in Liquid } \\
\text { Effluent Annual Report, WHC-EP-TBD. } \\
\text { Characterization information for each of the Phase I and II Streams is provided in } \\
\text { Hanford Site Stream-Specific Reports, WHC-EP-O342. Analytical data collected } \\
\text { during } 1993 \text { for the active streams is summarized in WHC-EP-TBD. }\end{array}$ & $\begin{array}{l}\text { WHC, } 1990 \\
\text { WHC, } 1994\end{array}$ & Nono. \\
\hline $\begin{array}{l}\text { Miscellaneous } \\
\text { Streams }\end{array}$ & $\begin{array}{l}\text { Status - A listing of the Miscellaneous Streams was attached to "Miscellaneous } \\
\text { Streams Plan and Schedule," Letter } 9401521 \text {. The Miscellaneous Streams will be } \\
\text { evaluated and dispositioned in accordance with the Plan and Schedule for } \\
\text { Disposition and Regulatory Compliance for Miscellaneous Streams. } \\
\text { DOE/RL-93-94. }\end{array}$ & $\begin{array}{l}\text { J.M. Hennig, } 1994 \\
\text { RL, 1994a }\end{array}$ & $\begin{array}{l}\text { - Further characterize the Miscellaneous Streams and } \\
\text { other waste streams as they are identified. } \\
\text { - Identify work needed to bring the Miscellaneous } \\
\text { Streams into regulatory compliance. }\end{array}$ \\
\hline $\begin{array}{l}\text { Other Waste } \\
\text { Streams }\end{array}$ & $\begin{array}{l}\text { Treatment and Disposal of Other Waste Streams - Other waste streams exist } \\
\text { which are not included with the Phase I and II Streams, or the Miscellaneous } \\
\text { Streams. Options for cleaning up the Hanford Site are being ovaluated which will } \\
\text { determine the final disposition of these streams. } \\
\text { New facilities will be needed to fulfill the cleanup mission. Additional wastes will } \\
\text { be generated which are not recycled or otherwise dispositioned. Discharges to } \\
\text { the environment must meet applicable regulatory requirements. } \\
\text { Potential sources of waste include: } \\
\text { - B Plant and PUREX Plant cleanout } \\
\text { - Solid waste treatment li.e., Waste Receiving and Processing (WRAP) Facilityl } \\
\text { and disposal (li.e., Category } 1 \text { and } 3 \text { low-level waste, low.lovel mixed waste, } \\
\text { and Environmental Restoration Disposal Facility (ERDF) leachate] } \\
\text { - N Reactor and 100-K East fuel storage basins } \\
\text { - Purgewater from monitoring wells } \\
\text { (Cont'd below) }\end{array}$ & TBD & $\begin{array}{l}\text { - Further characterize the Miscellaneous Streams and } \\
\text { other waste streams as they are identified. } \\
\text { - Determine the technical limitations of the } 200 \text { Area } \\
\text { ETF and } 300 \text { Area TEDF. } \\
\text { - Develop waste acceptance criteria for the } 200 \text { Area } \\
\text { ETF and } 300 \text { Area TEDF. } \\
\text { - Investigate the possibility of treating other waste } \\
\text { streams in the } 200 \text { Area ETF or } 300 \text { Area TEDF. } \\
\text { (Identify the wastes, characterize the wastes, } \\
\text { complete BAT evaluations, perform treatability tests, } \\
\text { estimate airborne emissions, determine permit } \\
\text { requirements, verify compliance with radiological } \\
\text { limits, assess impacts to plant operatlon, define } \\
\text { process and plant upgrades, etc.) }\end{array}$ \\
\hline
\end{tabular}


Table 1. Initial Conditions for the Liquid Effluents Program (cont'd).

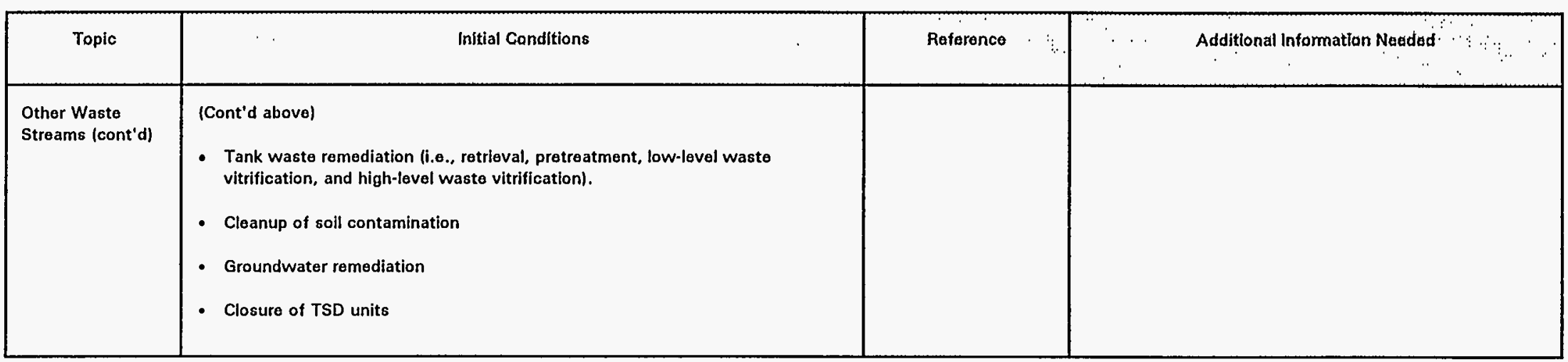


Table 2. Final Conditions for the Liquid Effluents Program.

\begin{tabular}{|c|c|c|c|}
\hline Topic & 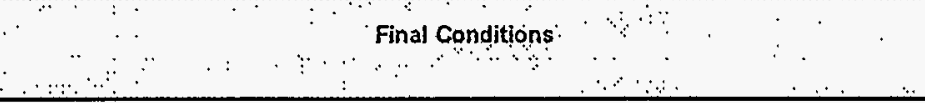 & Reference & Additional Infomaton Needed \\
\hline \multirow[t]{3}{*}{$\begin{array}{l}\text { Discharges to the } \\
\text { Environment }\end{array}$} & $\begin{array}{l}\text { Liquid Effluents - Wastewater discharges are provided with BAT/AKART methods } \\
\text { of prevention, control, and treatment, and comply with applicable discharge } \\
\text { permit requirements. }\end{array}$ & WHC.CM-7.5 & $\begin{array}{l}\text { - Investigate tritium treatment technologies for high- } \\
\text { volume/low-concentration waste streams. }\end{array}$ \\
\hline & $\begin{array}{l}\text { Gaseous Effluents - Radioactive airbome emissions do not exceed the derived } \\
\text { concentration guides (DCG) public values specified in WHC-CM-7-5, } \\
\text { Environmental Compliance, Appendix C. IThese criteria are specified in the Code } \\
\text { of Federal Regulations (CFR) at } 40 \text { CFR } 61 \text {. "National Emissions Standards for } \\
\text { Hazardous Air Pollutants".] } \\
\text { Emissions of contaminants which do not have specified maximum permissible } \\
\text { emission standards for work environments do not exceed the threshold values } \\
\text { found in WHC-CM-4-40, Industrial Hygiene Manual. }\end{array}$ & $\begin{array}{l}\text { WHC-CM-7-5 } \\
\text { WHC-CM-4-40 }\end{array}$ & None. \\
\hline & $\begin{array}{l}\text { Groundwater Quality - Primary and secondary contaminants and radionuclides in } \\
\text { the groundwater below a discharge site do not exceed the limits in WHC-CM-7-5, } \\
\text { Environmental Compliance, Table 8.1. [These criteria are specified in } \\
40 \text { CFR 141, "National Primary Drinking Water Regulations," and WAC 173-200, } \\
\text { "Water Quality Standards for Ground Waters of the State of Washington."] }\end{array}$ & WHC-CM-7-5 & None. \\
\hline \multirow[t]{2}{*}{$\begin{array}{l}\text { Items Transferred } \\
\text { to Others }\end{array}$} & $\begin{array}{l}\text { Solid Secondary Waste- Radioactive low-level waste and low-level mixed waste } \\
\text { meet the acceptance criteria for on-site storage and disposal in Hanford Site Solid } \\
\text { Waste Acceptance Criteria, WHC-EP-0063-4. }\end{array}$ & WHC, 1993 & $\begin{array}{l}\text { - Evaluate process and facility changes which may } \\
\text { onhance solid waste handling and disposal. }\end{array}$ \\
\hline & $\begin{array}{l}\text { Surplus Facilities - Surplus facilities meet the acceptance criteria for turnover for } \\
\text { deactivation and decommissioning at the end of the mission. [Requirements for } \\
\text { planning, facility designation, documentation, maintenance, security, and } \\
\text { provision of spare parts, equipment, and essential materials are specified in } \\
\text { WHC-CM-1-3, Management Requirements and Procedures, MRP 6.15, "Facility } \\
\text { Shutdown, Standby, and Transfer."] }\end{array}$ & WHC-CM-1-3 & $\begin{array}{l}\text { - Dovelop the accoptance criteria for turnover of surplus } \\
\text { facilities for deactivation and decommissioning. }\end{array}$ \\
\hline
\end{tabular}


Table 3. Programmatic Interfaces for the Liquid Effluents Program.

\begin{tabular}{|c|c|c|c|}
\hline Interface & Source of Constraint & Constraint on Mișsjon & Warking Position \\
\hline \multirow[t]{2}{*}{ U.S. Department of Energy (DOE) } & $\begin{array}{l}\text { DOE Orders } \\
\text { - DOE Order } 4700.1, \text { Project Management } \\
\text { System } \\
\text { - DOE Order } 5400.5, \text { Radiation Protection } \\
\text { of the Public and the Environment } \\
\text { - DOE Order } 5440.1 \text { E, National } \\
\text { Environmental Policy Act Compllance } \\
\text { Program } \\
\text { - DOE Order } 5480.4, \text { Environmental } \\
\text { Protection, Safety, and Health Protection } \\
\text { Standards } \\
\text { - DOE Order } 5480.11, \text { Radiation Protection } \\
\text { for Occupational Workers } \\
\text { - DOE Order } 5480.19, \text { Conduct of } \\
\text { Operations Requirements for DOE } \\
\text { Facilities } \\
\text { - DOE Order } 5483.1 \mathrm{~A}, \text { Occupational } \\
\text { Safety and Health Program for DOE } \\
\text { Contractor Employees at Government- } \\
\text { Owned Contractor-Operated Facilities } \\
\text { - DOE Order } 5700.6 \mathrm{C}, \text { Quality Assurance } \\
\text { - DOE Order } 5820.2 \mathrm{~A}, \text { Radioactive Waste } \\
\text { Management } \\
\text { - DOE Order } 6430.1 \mathrm{~A}, \text { General Design } \\
\text { Criteria }\end{array}$ & $\begin{array}{l}\text { Establish policies, organizations, methods, } \\
\text { standards, or procedures; guide, instruct, } \\
\text { and inform contractors in their work; and } \\
\text { require action or performance of certain } \\
\text { work. }\end{array}$ & $\begin{array}{l}\text { Now systems or facilities will be designed, } \\
\text { constructed, and operated in accordance with } \\
\text { current regulations, codes, standards, and } \\
\text { directives. A graded approach to compliance } \\
\text { will be developed for existing faclitites, based } \\
\text { on risk and importance to safety and } \\
\text { protection of the environment. Exemptions } \\
\text { may be sought to reduce costs and/or } \\
\text { expedite cleanup of the Hanford Site. }\end{array}$ \\
\hline & $\begin{array}{l}\text { Budget } \\
\text { - Activity data sheets (ADS) system }\end{array}$ & $\begin{array}{l}\text { Total budget and funding profile limit work } \\
\text { scope. Flexibility to move funds in response } \\
\text { to changing priorities is limited. }\end{array}$ & $\begin{array}{l}\text { Prioritize cleanup objectives. Develop } \\
\text { strategy for maximum benefit. Focus on } \\
\text { waste streams with greatest impact to } \\
\text { environment. }\end{array}$ \\
\hline
\end{tabular}


Table 3. Programmatic Interfaces for the Liquid Effluents Program (cont'd).

\begin{tabular}{|c|c|c|c|}
\hline $\begin{array}{cc}\cdots & \text { Interface. } \\
\end{array}$ & $\therefore \quad \begin{array}{c}\text { Source of Constraint } \\
\therefore\end{array}$ & $\therefore \quad$ Constralnt on Mtssion $: \cdots$ & working position \\
\hline U.S. Department of Energy (DOE) (cont'd) & $\begin{array}{l}\text { Schedule } \\
\text { - Tri-Party Agreement milestone M-17-00 } \\
\text { (operation, treatment, and disposal of } \\
\text { liquid effluents) } \\
\text { - Tri-Party Agreement milestone M-26-03 } \\
\text { (cease discharge to LERF) } \\
\text { - Tri-Party Agreement milestone M-26-04 } \\
\text { (remove hazardous waste residue from } \\
\text { LERF) } \\
\text { - Tri-Party Agreement milestone M-26-05 } \\
\text { (report on tritium treatment technology) }\end{array}$ & $\begin{array}{l}\text { Schedule constraints limit time available for } \\
\text { technology development and duration of } \\
\text { testing. }\end{array}$ & $\begin{array}{l}\text { Work to schedule as possible. Assure } \\
\text { protection of public health, worker safety, and } \\
\text { the environment. Submit change requests to } \\
\text { adjust Tri-Party Agreement milestones } \\
\text { affected by changes in budget or work scope. }\end{array}$ \\
\hline $\begin{array}{l}\text { U.S. Department of Energy, Richland } \\
\text { Operations Office (RL) }\end{array}$ & $\begin{array}{l}\text { RL Orders } \\
\text { - RL. Order } 5480.4 \mathrm{C} \text {, Environmental } \\
\text { Protection, Safety, and Health Protection } \\
\text { Standards for RL. } \\
\text { - RL Order } 6430.1 \mathrm{C} \text {, Hanford Plant } \\
\text { Standards (HPS) Program }\end{array}$ & $\begin{array}{l}\text { Establish policies, organizations, mothods, } \\
\text { standards, or procedures; gulde, instruct, } \\
\text { and inform contractors in their work; and } \\
\text { require action or performance of certain } \\
\text { work. }\end{array}$ & $\begin{array}{l}\text { New systems or facilitles will be designed, } \\
\text { constructed, and operated in accordance with } \\
\text { current regulations, codes, standards, and } \\
\text { directives. A graded approach to compliance } \\
\text { will be developed for existing facilities, based } \\
\text { on risk and importance to safety and } \\
\text { protection of the environment. Exemptions } \\
\text { may be sought to reduce costs and/or } \\
\text { oxpedite cleanup of the Hanford Site. }\end{array}$ \\
\hline U.S. Environmental Protection Agency (EPA) & $\begin{array}{l}\text { Statutes } \\
\text { - Clean Air Act } \\
\text { - Clean Water Act } \\
\text { - National Environmental Pollcy Act (NEPA) } \\
\text { - Resource Conservation and Recovery Act } \\
\text { (RCRA) } \\
\text { - Safe Drinking Water Act } \\
\text { - Toxic Substances Control Act } \\
\text { (Cont'd below) }\end{array}$ & $\begin{array}{l}\text { Define cleanup goals and set timetable; } \\
\text { prescribe requirements for treatment } \\
\text { tochnology, characterization, and } \\
\text { monitoring; specify design and construction } \\
\text { standards; limit liquid and gaseous effluents; } \\
\text { identify permitting, documentation, and } \\
\text { reporting needs. }\end{array}$ & $\begin{array}{l}\text { Comply as required. Negotiate alternate } \\
\text { compliance strategy or obtain exemptlons as } \\
\text { noeded. }\end{array}$ \\
\hline
\end{tabular}


Table 3. Programmatic Interfaces for the Liquid Effluents Program (cont'd).

\begin{tabular}{|c|c|c|c|}
\hline Interface & Source of Constraint & Constraint on Mission & Working Positian \\
\hline $\begin{array}{l}\text { U.S. Environmental Protection Agency (EPA) } \\
\text { (cont'd) }\end{array}$ & $\begin{array}{l}\text { (Cont'd above) } \\
\text { Code of Federal Requlations } \\
\text { - } 40 \text { CFR } 52 \text {, "Approval and Promulgation } \\
\text { of Implementation Plans" } \\
\text { - } 40 \text { CFR } 61 \text {, "National Emission Standards } \\
\text { for Hazardous Air Pollutants" } \\
\text { - } 40 \text { CFR 121, "State Certification of } \\
\text { Activities Requiring Federal License or } \\
\text { Permit" } \\
\text { - } 40 \text { CFR 122, "EPA Administered Permit } \\
\text { Programs: The National Pollutant } \\
\text { Discharge Elimination System" } \\
\text { - } 40 \text { CFF 129, "Toxic Pollutant Effluent } \\
\text { Standards" } \\
\text { - } 40 \text { CFR 260, "Hazardous Waste } \\
\text { Management System: General" } \\
\text { - } 40 \text { CFR 261, "Identification and Listing } \\
\text { of Hazardous Waste" } \\
\text { - } 40 \text { CFR 262, "Standards Applicable to } \\
\text { Generators of Hazardous Waste" } \\
\text { - } 40 \text { CFR 263, "Standards Applicable to } \\
\text { Transporters of Hazardous Waste" } \\
\text { - } 40 \text { CFR 264, "Standards for Owners and } \\
\text { Operators of Hazardous Waste } \\
\text { Treatment, Storage, and Disposal } \\
\text { Facilities" } \\
\text { - } 40 \text { CFR 265, "Interim Status Standards } \\
\text { tor Owners and Operators of Hazardous } \\
\text { Waste Treatment, Storage, and Disposal } \\
\text { Facilities" } \\
\text { (Cont'd below) }\end{array}$ & • & \\
\hline
\end{tabular}


Table 3. Programmatic Interfaces for the Liquid Effluents Program (cont'd).

\begin{tabular}{|c|c|c|c|}
\hline $\begin{array}{l}\therefore \quad \cdots \quad \text { interface } \\
\therefore\end{array}$ & Source of Constraint & $\because \quad$ Constraint on mission & $\because$ watking positao \\
\hline $\begin{array}{l}\text { U.S. Environmental Protection Agency (EPA) } \\
\text { (cont'd) }\end{array}$ & $\begin{array}{l}\text { (Cont'd above) } \\
\text { - } 40 \text { CFR 268, "Land Disposal } \\
\text { Restrictions" } \\
\text { - } 40 \text { CFR 270, "EPA Administered Permit } \\
\text { Programs: The Hazardous Waste Permit } \\
\text { Program" }\end{array}$ & & $\cdot$ \\
\hline
\end{tabular}


Table 3. Programmatic Interfaces for the Liquid Effluents Program (cont'd).

\begin{tabular}{|c|c|c|c|}
\hline Interface & Saurce of Constraint & Constraint on Mlaston & $\therefore \quad$ Warkțing Postitlann: \\
\hline $\begin{array}{l}\text { Washington State Department of Ecology } \\
\text { (Ecology) (cont'd) }\end{array}$ & $\begin{array}{l}\text { (Cont'd above) } \\
\text { Washington Administrative Code } \\
\text { - WAC 173-201, "Water Quality Standards } \\
\text { for Surface Waters of the State of } \\
\text { Washington" } \\
\text { - WAC 173-216, "State Waste Discharge } \\
\text { Permit Program" } \\
\text { - WAC 173-218, "Underground Injection } \\
\text { Control Program" } \\
\text { - WAC 173-240, "Submission of Plans and } \\
\text { Reports for Construction of Wastewater } \\
\text { Facilities" } \\
\text { - WAC 173-303, "Dangerous Waste } \\
\text { Regulations" } \\
\text { - WAC 173-400, "General Regulations for } \\
\text { Air Pollution Sources" } \\
\text { - WAC 173-460, "Controls for Now } \\
\text { Sources of Toxic Air Pollutants" } \\
\text { - WAC 173-480, "Amblent Air Quality } \\
\text { Standards and Emission Limits for } \\
\text { Radionuclides" } \\
\text { - WAC 197-11, "SEPA Rules" } \\
\text { - WAC 220-110, "Hydraulic Code Rules" } \\
\text { - WAC 246-247, "Radiation Protection- } \\
\text { Air Emissions" } \\
\text { - WAC 246-272, "On-site Sewage } \\
\text { System" } \\
\text { Other } \\
\text { - Consent Order No. DE } 91 \text { NM-177 }\end{array}$ & & \\
\hline
\end{tabular}


Table 3. Programmatic Interfaces for the Liquid Effluents Program (cont'd).

\begin{tabular}{|c|c|c|c|}
\hline 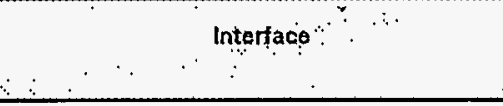 & 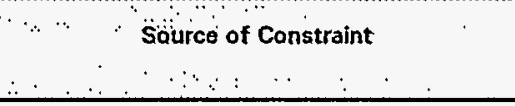 & $\begin{array}{r}\text { Constraint on Mission } \\
\hdashline\end{array}$ & Working Position \\
\hline $\begin{array}{l}\text { Other state regulatory agencies } \\
\text { - Washington State Department of Health } \\
\text { - Washington State Department of Labor } \\
\text { and Industries }\end{array}$ & TBD & TBD & $\begin{array}{l}\text { Comply as required. Negotiate alternate } \\
\text { compliance strategy or obtain exemptions as } \\
\text { needed. }\end{array}$ \\
\hline $\begin{array}{l}\text { Local regulatory agencies } \\
\text { - Benton-Franklin-Walla Walla Counties Air } \\
\text { Pollution Control Authority } \\
\text { - Benton-Franklin County Health District } \\
\text { - City of Richland }\end{array}$ & $\begin{array}{l}\text { Regulations } \\
\text { - General Regulation 80-7 } \\
\text { - Benton-Franklin County Health District } \\
\text { Department Guidelines (for sanitary } \\
\text { facilities) } \\
\text { - City of Richland Ordinance No. 35-84, } \\
\text { "Richland Protreatment Ordinance" }\end{array}$ & $\begin{array}{l}\text { Applies where state regulations do not. } \\
\text { Establishes standards for maximum } \\
\text { permissible air emissions, requires } \\
\text { registration of new sources, and provides } \\
\text { for monitoring and reporting. Specifies } \\
\text { design requirements for sanitary facilities. } \\
\text { Limits discharges to City of Richland POTW. }\end{array}$ & $\begin{array}{l}\text { Comply as required. Negotiate alternate } \\
\text { compliance strategy or obtain exemptions as } \\
\text { needed. }\end{array}$ \\
\hline Nativo Americans & Stakeholders & $\begin{array}{l}\text { Affect technical solutions, schedules, and } \\
\text { program execution. }\end{array}$ & $\begin{array}{l}\text { Involve affected Native Americans in planning } \\
\text { and decision-making. }\end{array}$ \\
\hline Public & Stakeholders & $\begin{array}{l}\text { Affect technical solutions, schedules, and } \\
\text { program execution. }\end{array}$ & $\begin{array}{l}\text { Involve public in planning and decision- } \\
\text { making. }\end{array}$ \\
\hline Westinghouse Hanford Company (WHC) & $\begin{array}{l}\text { WHC-CM-(controlled manuals) } \\
\text { - WHC-CM-1-3, Management } \\
\text { Requirements and Procedures } \\
\text { - WHC-CM-1-5, Standard Operating } \\
\text { Practices } \\
\text { - WHC-CM-1-6, Radiological Control } \\
\text { Manual } \\
\text { - WHC-CM-2-14, Hazardous Material } \\
\text { Packaging and Shipping } \\
\text { - WHC-CM-4-2, Quality Assurance Manual } \\
\text { (Cont'd below) }\end{array}$ & $\begin{array}{l}\text { Include administrative procedures, policies, } \\
\text { and requirements for design, construction, } \\
\text { operations, maintenance, decommissioning, } \\
\text { project control, procurement, environmental } \\
\text { protection, public health and worker safety, } \\
\text { and quality assurance. }\end{array}$ & $\begin{array}{l}\text { Comply as required. Exemptlons shall be in } \\
\text { accordance with WHC-CM-1-3, MRP } 2.21 \text {, } \\
\text { "Controlled Manual Waiver Process." }\end{array}$ \\
\hline
\end{tabular}


Table 3. Programmatic Interfaces for the Liquid Effluents Program (cont'd).

\begin{tabular}{|c|c|c|c|}
\hline Interface & Saurce of Canstraint & Constraint on Mision & Working Posittlan \\
\hline $\begin{array}{l}\text { Westinghouse Hanford Company (WHC) } \\
\text { (cont'd) }\end{array}$ & $\begin{array}{l}\text { (Cont'd aboval } \\
\text { - WHC-CM-4-3, Industrial Safety Manual } \\
\text { - WHC-CM-4-9, Radiological Design } \\
\text { - WHC-CM-4-11, ALARA Program Manual } \\
\text { - WHC-CM-4-40, Industrial Hygiene } \\
\text { Manual } \\
\text { - WHC-CM-4-41, Fire Protection Program } \\
\text { Manual } \\
\text { - WHC-CM-4-46, Nonreactor Facility } \\
\text { Safety Analysis Manual } \\
\text { - WHC-CM-5-16, Solid Waste } \\
\text { Management } \\
\text { - WHC-CM-6-1, Standard Engineering } \\
\text { Practices } \\
\text { - WHC-CM-6-2, Project Management } \\
\text { - WHC-CM-7-5, Environmental Compliance }\end{array}$ & & \\
\hline
\end{tabular}


Table 4. Physical Interfaces for the Liquid Effluents Program.

\begin{tabular}{|c|c|c|c|}
\hline$\therefore \quad \therefore \quad \vdots \quad \because n \quad \because \cdots$ & 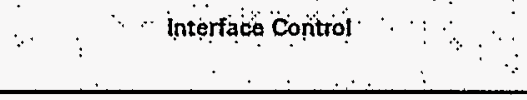 & $\therefore \quad$ Constraint on Mission & W Worktng Position \\
\hline Waste Streams Received for Treatment & $\begin{array}{l}\text { Project W-049H Interface Control } \\
\text { Document, WHC-SD-WO49H-ICD-001 } \\
\text { (Benton 1992) } \\
\text { Interface control document(s) for other } \\
\text { incoming waste stroams - TBD }\end{array}$ & $\begin{array}{l}\text { Limits alternatives for treatment. } \\
\text { Determines process throughput, availability, } \\
\text { and lag storage needs. }\end{array}$ & $\begin{array}{l}\text { Develop interface control document(s). Limit } \\
\text { by acceptance criteria for treatment facility. } \\
\text { May require pretreatment. }\end{array}$ \\
\hline Solid Secondary Waste Transferred to Others & $\begin{array}{l}\text { Interface Control Document Between Liquid } \\
\text { Effluent Senvices and Solid Waste Disposal, } \\
\text { WHC-SD-WM-PICD-001 (Carlson 1994). }\end{array}$ & $\begin{array}{l}\text { Affects waste form. package, and } \\
\text { documentation. }\end{array}$ & Comply with interface control document. \\
\hline Surplus Facilities Transferred to Others & $\begin{array}{l}\text { Interface control document(s) for surplus } \\
\text { facilities - TBD }\end{array}$ & $\begin{array}{l}\text { Requires advance planning. Facility design } \\
\text { to incorporate features that simplify and } \\
\text { facilitate decommissioning. }\end{array}$ & $\begin{array}{l}\text { Develop interface control document(s). Limit } \\
\text { by acceptance criteria for tumover for } \\
\text { deactivation and decommissioning. }\end{array}$ \\
\hline Treatment Technology & TBD & $\begin{array}{l}\text { Limits alternatives for treatment. Restricts } \\
\text { schedule to implement. Impacts program } \\
\text { cost. }\end{array}$ & $\begin{array}{l}\text { Determine functional requirements for } \\
\text { program. Identify and prioritize technology } \\
\text { needs. Coordinate with sitewide technology } \\
\text { development. }\end{array}$ \\
\hline Site Infrastructure & TBD & $\begin{array}{l}\text { Affects facility design, construction, and } \\
\text { operation. Impacts program cost. }\end{array}$ & $\begin{array}{l}\text { Identify support needed. Characterize local } \\
\text { conditions, develop design inputs, document } \\
\text { interfaces, adhere to change control process. }\end{array}$ \\
\hline
\end{tabular}


Figure 1. Physical Interfaces for the Phase I and II Streams.
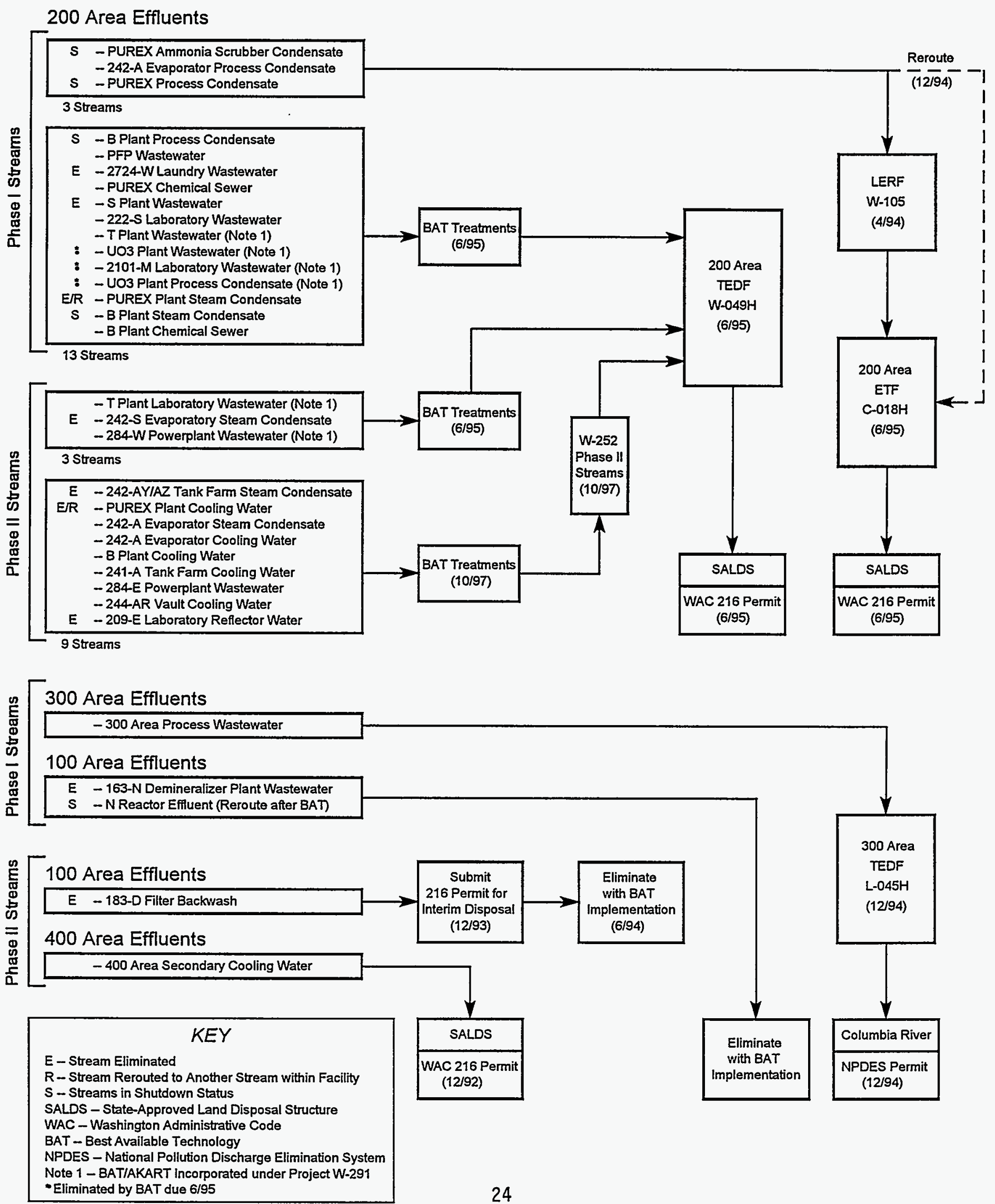

300 Area
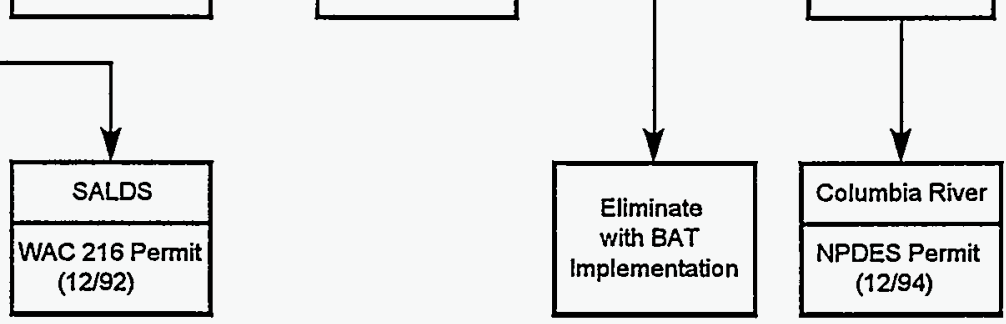
Figure 2. Physical Interfaces for Liquid Effluents in the 300 Area.

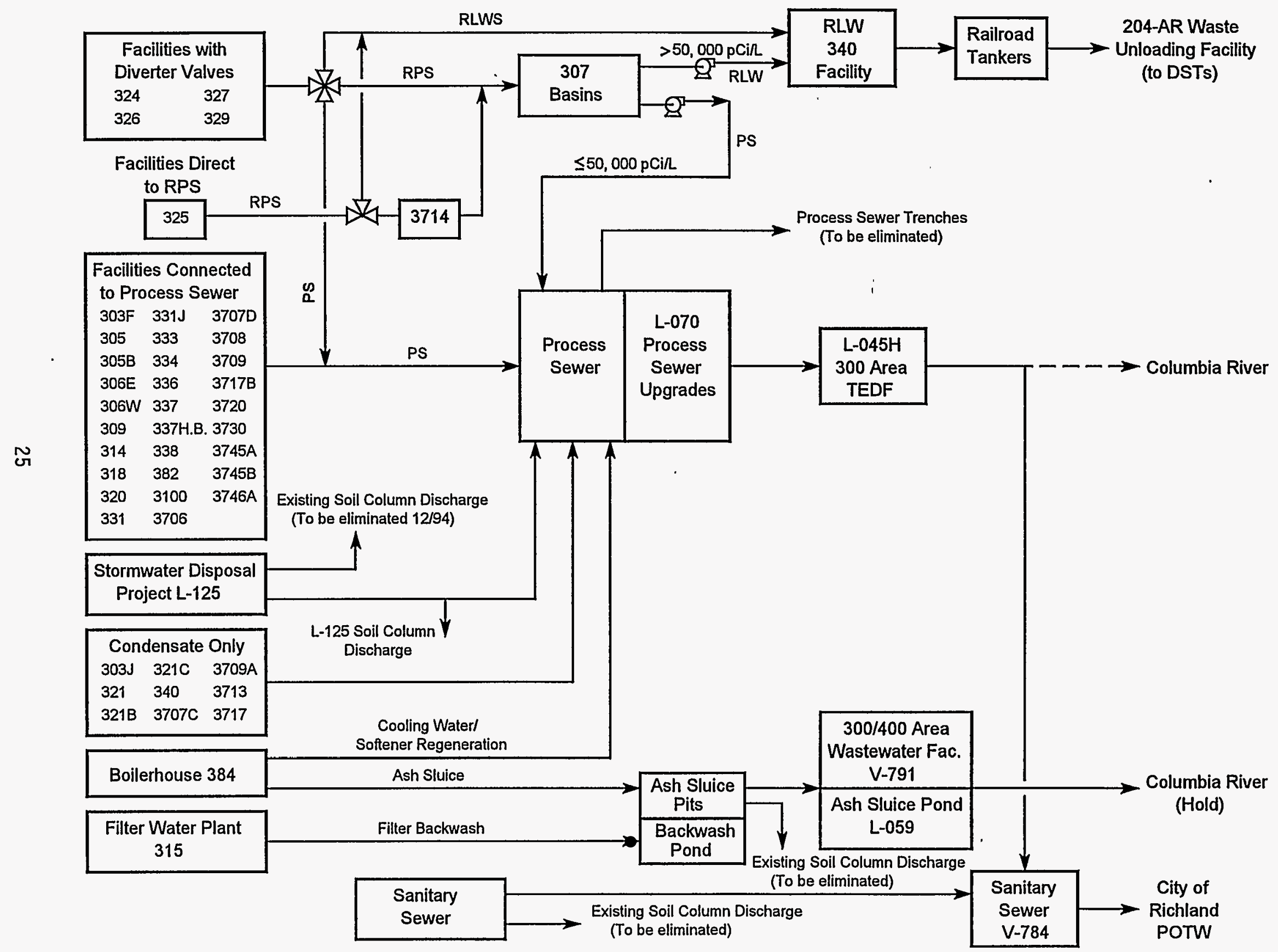


WHC-SD-WM-MAR-003 Rev. 0

Table 5. Measures of Success for the Liquid Effluents Program.

\begin{tabular}{|c|c|}
\hline Category & Measures of Success \\
\hline Environmental Protection & $\begin{array}{l}\text { - Eliminate unpermitted discharges to the soil } \\
\text { column. }\end{array}$ \\
\hline Public Health & $\begin{array}{l}\text { - Protect the groundwater. } \\
\text { - Minimize public exposure to radioactive and } \\
\text { hazardous materials. }\end{array}$ \\
\hline Worker Safety & $\begin{array}{l}\text { - Minimize industrial hazards. } \\
\text { - Minimize worker exposure to radioactive and } \\
\text { hazardous materials. }\end{array}$ \\
\hline Regulatory Comp 1 iance & $\begin{array}{l}\text { - Comply with discharge permits. } \\
\text { - Minimize the volume of system-generated } \\
\text { waste. } \\
\text { - Avoid regulatory uncertainty. }\end{array}$ \\
\hline Treatment Technology & $\begin{array}{l}\text { - Demonstrate the effectiveness of treatment. } \\
\text { - Assure treatment system reliability. } \\
\text { - Continue essential operations. } \\
\text { - Position the Hanford Site for future work. }\end{array}$ \\
\hline Cost & $\begin{array}{l}\text { - Minimize the cost of treatment and disposal. } \\
\text { - Minimize life-cycle cost. }\end{array}$ \\
\hline Schedute & $\begin{array}{l}\text { - Fulfill Tri-Party Agreement and Consent Order } \\
\text { milestones. } \\
\text { - Support cleanup of the Hanford Site. } \\
\text { - Minimize the time to resolve safety concerns. }\end{array}$ \\
\hline
\end{tabular}


Table 6. Additional Information Needed for the Liquid Effluents Program.

\begin{tabular}{|c|c|c|}
\hline $\begin{array}{llll}\text { Information Needed } & & \\
& \cdots & \vdots\end{array}$ & 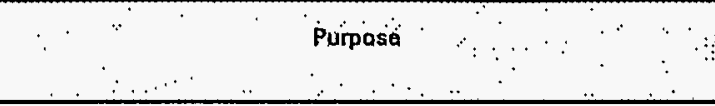 & 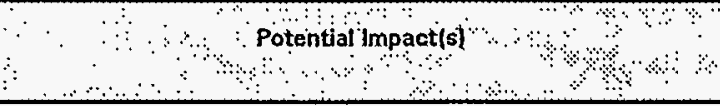 \\
\hline $\begin{array}{l}\text { Determine the treatment requirements for the } \mathrm{N} \text { Reactor } \\
\text { effluent. }\end{array}$ & $\begin{array}{l}\text { Provide cost-effective treatment and disposal. Ensure } \\
\text { environmental compliance. }\end{array}$ & $\begin{array}{l}\text { - Regulations which protect the public health and } \\
\text { onvironment may be violated. }\end{array}$ \\
\hline $\begin{array}{l}\text { Further characterize the Miscellaneous Streams and other } \\
\text { waste streams as they are identified. }\end{array}$ & $\begin{array}{l}\text { Characterization information is an input to treatment } \\
\text { technology selection and facility design. }\end{array}$ & $\begin{array}{l}\text { - Inadequate treatment may be provided or procass } \\
\text { throughput may be impacted by waste streams } \\
\text { significantly different from design basis. } \\
\text { - Treatment facility may be over-designed. } \\
\text { - Plant capacity may be inadequate. } \\
\text {. }\end{array}$ \\
\hline $\begin{array}{l}\text { Identify work needed to bring the Miscellaneous Streams into } \\
\text { regulatory compliance. }\end{array}$ & Scope of work is undefined. & $\begin{array}{l}\text { - Regulations which protect the public health and } \\
\text { environment may be violated. }\end{array}$ \\
\hline $\begin{array}{l}\text { Determine the technical limitations of the } 200 \text { Area ETF and } \\
300 \text { Area TEDF. }\end{array}$ & $\begin{array}{l}\text { Ensure environmental compliance. Define limits for safo } \\
\text { operation. }\end{array}$ & $\begin{array}{l}\text { - Liquid and gaseous effluents may violate discharge } \\
\text { permits. } \\
\text { - Solid secondary waste may not meet acceptance criteria } \\
\text { for on-site storage and disposal. } \\
\text { - Unsafe conditions may exist. }\end{array}$ \\
\hline $\begin{array}{l}\text { Develop waste acceptance criteria for the } 200 \text { Area ETF and } \\
300 \text { Area TEDF. }\end{array}$ & $\begin{array}{l}\text { Range of foeds which can be acceptably treated is unknown. } \\
\text { Use acceptance criteria to ovaluate possibility of treating } \\
\text { other waste streams. }\end{array}$ & $\begin{array}{l}\text { - Inadequate treatment may be provided or process } \\
\text { throughput may be impacted by waste streams } \\
\text { significantly different from design basis. }\end{array}$ \\
\hline $\begin{array}{l}\text { Investigate the possibility of treating other waste streams in } \\
\text { the } 200 \text { Area ETF or } 300 \text { Area TEDF. (Identify the wastes, } \\
\text { characterize the wastes, complete BAT evaluations, perform } \\
\text { treatability tests, estimate alrborne emissions, determine } \\
\text { permit requirements, verify compliance with radiological } \\
\text { limits, assess impacts to plant operation, define process and } \\
\text { plant upgrades, etc.) }\end{array}$ & Suitable treatment capacity may already oxist. & $\begin{array}{l}\text { - Unnecessary costs may be incurred for providing similar } \\
\text { treatment olsewhere. } \\
\text { - Overall funding limits may delay cleanup schedule. }\end{array}$ \\
\hline
\end{tabular}


Table 6. Additional Information Needed for the Liquid Effluents Program (cont'd).

\begin{tabular}{|c|c|c|}
\hline Information Needed & Purposa & Potontial Impact(s) . \\
\hline $\begin{array}{l}\text { Investigate tritium treatment technologies for high-volume/ } \\
\text { low-concentration waste streams. }\end{array}$ & $\begin{array}{l}\text { Concentration of tritium in treated liquid effluents discharged } \\
\text { to the environment may not be acceptable. Investigation of } \\
\text { tritium treatment technologies is required by the Tri-Party } \\
\text { Agreement. }\end{array}$ & $\begin{array}{l}\text { - Regulations which protect the public health and } \\
\text { environment may be violated. }\end{array}$ \\
\hline $\begin{array}{l}\text { Evaluate process and facility changes which may enhance } \\
\text { solid waste handling and disposal. }\end{array}$ & $\begin{array}{l}\text { Provide cost-effectivo treatment and disposal. Ensure } \\
\text { compliance with acceptance criteria. }\end{array}$ & $\begin{array}{l}\text { - Unnecessary costs may be incurred for solid wasto } \\
\text { handling and disposal. }\end{array}$ \\
\hline $\begin{array}{l}\text { Develop the acceptance criteria for turnover of surplus } \\
\text { facilities for deactivation and decommissioning. }\end{array}$ & $\begin{array}{l}\text { Deactivation and decommissioning is a consideration in } \\
\text { facility design and requires advance planning. }\end{array}$ & $\begin{array}{l}\text { - Cost increases and schedule delays may result for } \\
\text { modifications to meet acceptance criteria. }\end{array}$ \\
\hline
\end{tabular}


WHC-SD-WM-MAR-003 Rev. 0

\subsection{REFERENCES}

\section{Code of Federal Regulations}

40 CFR 52, "Approval and Promulgation of Implementation Plans," Code of Federal Regulations, as amended.

40 CFR 61, "National Emissions Standards for Hazardous Air Pollutants, " Code of Federal Regulations, as amended.

40 CFR 121, "State Certification of Activities Requiring Federal License or Permit," Code of Federal Regulations, as amended.

40 CFR 122, "EPA Administered Permit Programs: The National Pollutant Discharge Elimination System," Code of Federal Regulations, as amended:

40 CFR 129, "Toxic Pollutant Effluent Standards," Code of Federal Regulations, as amended.

40 CFR 141, "National Primary Drinking Water Regulations," Code of Federa7 Regulations, as amended.

40 CFR 260, "Hazardous Waste Management System: General," Code of Federal Regulations, as amended.

40 CFR 261, "Identification and Listing of Hazardous Waste," Code of Federa7 Regulations, as amended.

40 CFR 262, "Standards App1icable to Generators of Hazardous Waste," Code of Federal Regulations, as amended.

40 CFR 263, "Standards Applicable to Transporters of Hazardous Waste," Code of Federal Regulations, as amended.

40 CFR 264, "Standards for Owners and Operators of Hazardous Waste Treatment, Storage, and Disposal Facilities," Code of Federal Regulations, as amended.

40 CFR 265, "Interim Status Standards for Owners and Operators of Hazardous Waste Treatment, Storage, and Disposal Facilities," Code of Federal Regulations, as amended.

40 CFR 268, "Land Disposal Restrictions," Code of Federal Regulations, as amended.

40 CFR 270, "EPA Administered Permit Programs: The Hazardous Waste Permit Program," Code of Federal ReguTations, as amended.

49 CFR 100-179, "Department of Transportation Hazardous Materials Regulations," Code of Federal Regulations, as amended. 


\section{Public Laws}

Benton-Franklin-Walla Walla Counties Air Pollution Control Authority, 1980, General Regulation 80-7, Richland, Washington.

Benton-Frankl in County Health District, Benton-Franklin County Health District Department Guidelines (for sanitary facilities).

City of Richland, City of Richland Ordinance No. 35-84, "Richland Pretreatment Ordinance."

Clean Air Act of 1977, as amended, 42 USC 7401, et seq.

Clean Water Act of 1977, as amended, 33 USC 1251, et seq.

Comprehensive Environmenta7 Response, Compensation, and Liability Act of 1980, as amended, 42 USC 9601, et seq.

Hazardous Materials Transportation Act, as amended, 49 USC 1801, et seq.

Model Toxics Control Act, Revised Code of Washington, RCW 70.105D, 01 ympia, Washington.

National Environmental Po7icy Act of 1969, as amended, 42 USC 4321 , et seq.

Resource Conservation and Recovery Act of 1976, as amended, 42 USC 6901, et seq.

Safe Drinking Water Act, as amended, 42 USC 300, et seq.

State Environmental Policy Act of 1971, Revised Code of Washington, RCW 43.21C, 07ympia, Washington

Toxic Substances Control Act, as amended, 15 USC 2601, et seq.

Washington Clean Air Act., Revised Code of Washington, RCW 70.94, 01ympia, Washington.

Washington Hazardous Waste Management Act, Revised Code of Washington, RCW 70.105, 01ympia, Washington.

Water Pollution Control Act, Revised Code of Washington, RCW 90.48, 01ympia, Washington.

\section{U.S. Department of Energy Orders}

DOE Order 4700.1, Project Management System, U.S. Department of Energy, Washington, D.C.

DOE Order 5400.5, Radiation Protection of the Public and the Environment, U.S. Department of Energy, Washington, D.C. 
DOE Order 5440.1E, National Environmenta7 Policy Act Compliance Program, U.S. Department of Energy, Washington, D.C.

DOE Order 5480.4, Environmental Protection, Safety, and Hea7th Protection Standards, U.S. Department of Energy, Washington, D.C.

DOE Order 5480.11, Radiation Protection for Occupational Workers, U.S. Department of Energy, Washington, D.C.

DOE Order 5480.19, Conduct of Operations Requirements for DOE Facilities, U.S. Department of Energy, Washington, D.C.

DOE Order 5483.1A, Occupational Safety and Health Program for DOE Contractor Employees at Government-Owned Contractor-Operated Facilities, U.S. Department of Energy, Washington, D.C.

DOE Order 5700.6C, Qua7ity Assurance, U.S. Department of Energy, Washington, D.C.

DOE Order 5820.2A, Radioactive Waste Management, U.S. Department of Energy, Washington, D.C.

DOE Order 6430.1A, Genera7 Design Criteria, U.S. Department of Energy, Washington, D.C.

U.S. Department of Energy, Richland Operations Office, Orders and Implementing Procedures

RL Order 5480.4C, Environmental Protection, Safety, and Hea7th Protection Standards for RL, U.S. Department of Energy, Richland Operations Office, Richland, Washington.

RL Order 6430.1C, Hanford Plant Standards (HPS) Program, U.S. Department of Energy, Richland Operations Office, Richland, Washington.

RLPD 4900.1, 1994, Systems Engineering, U.S. Department of Energy, Richland Operations Office, Richland, Washington.

Washington Administrative Code

WAC 173-14, "Permits for Developments on Shorelines of the State," Washington Administrative Code, as amended.

WAC 173-200, "Water Quality Standards for Ground Waters of the State of Washington," Washington Administrative Code, as amended.

WAC 173-201, "Water Quality Standards for Surface Waters of the State of Washington," Washington Administrative Code, as amended.

WAC 173-216, "State Waste Discharge Permit Program," Washington Administrative Code, as amended. 


$$
\text { WHC-SD-WM-MAR-003 Rev. } 0
$$

WAC 173-218, "Underground Injection Control Program," Washington Administrative Code, as amended.

WAC 173-240, "Submission of Plans and Reports for Construction of Wastewater Facilities," Washington Administrative Code, as amended.

WAC 173-303, "Dangerous Waste Regulations," Washington Administrative Code, as amended.

WAC 173-400, "General Regulations for Air Pollution Sources," Washington Administrative Code, as amended.

WAC 173-460, "Controls for New Sources of Toxic Air Pollutants," Washington Administrative Code, as amended.

WAC 173-480, "Ambient Air Quality Standards and Emission Limits for Radionuclides," Washington Administrative Code, as amended.

WAC 197-11, "SEPA Rules," Washington Administrative Code, as amended.

WAC 220-110, "Hydrautic Code Rules," Washington Administrative Code, as amended.

WAC 246-247, "Radiation Protection - Air Emissions," Washington Administrative Code, as amended.

WAC 246-272, "On-site Sewage System," Washington Administrative Code, as amended.

\section{Westinghouse Hanford Company Controlled Manuals}

WHC-CM-1-3, Management Requirements and Procedures, Westinghouse Hanford Company, Richland, Washington.

WHC-CM-1-5, Standard Operating Practices, Westinghouse Hanford Company, Richland, Washington.

WHC-CM-1-6, Radiological Control Manua7, Westinghouse Hanford Company, Richland, Washington.

WHC-CM-2-14, Hazardous Material Packaging and Shipping, Westinghouse Hanford Company, Richland, Washington.

WHC-CM-4-2, Quality Assurance Manual, Westinghouse Hanford Company, Richland, Washington.

WHC-CM-4-3, Industria7 Safety Manua7, Westinghouse Hanford Company, Rich1and, Washington.

WHC-CM-4-9, Radiologica7 Design, Westinghouse Hanford Company, Rich7and, Washington. 
WHC-CM-4-11, ALARA Program Manua7, Westinghouse Hanford Company, Richland, Washington.

WHC-CM-4-40, Industrial Hygiene Manual, Westinghouse Hanford Company, Richland, Washington.

WHC-CM-4-41, Fire Protection Program Manual, Westinghouse Hanford Company, Richland, Washington.

WHC-CM-4-46, Nonreactor Facility Safety Analysis Manua7, Westinghouse Hanford Company, Richland, Washington.

WHC-CM-5-16, Solid Waste Management, Westinghouse Hanford Company, Richland, Washington.

WHC-CM-6-1, Standard Engineering Practices, Westinghouse Hanford Company, Richl and, Washington.

WHC-CM-6-2, Project Management, Westinghouse Hanford Company, Richland, Washington.

WHC-CM-7-5, Environmental Compliance, Westinghouse Hanford Company, Richland, Washington.

\section{Other Documents}

Benton, J.B., 1992, Project W-O49H Interface Control Document, WHC-SD-W049H-ICD-001, Revision 0, Westinghouse Hanford Company, Richland, Washington.

Carlson, A.B., 1994, Interface Control Document Between Liquid Effluent Services and Solid Waste Disposa7, WHC-SD-WM-PICD-001, Revision 0, Westinghouse Hanford Company, Richland, Washington.

DiLiberto, A.J., 1994, Liquid Eff7uents FY 1995 Multi-Year Program P7an, WHC-SP-1097, Westinghouse Hanford Company, Richland, Washington.

Ecology, 1991, Consent Order No. DE 91NM-177, Washington State Department of Ecology, 01ympia, Washington.

Ecology, EPA, and DOE, 1994, Hanford Federal Facility Agreement and Consent Order, 2 vols., as amended, Washington State Department of Ecology, U.S. Environmental Protection Agency, and U.S. Department of Energy, 01 ympia, Washington.

Hennig, J.M., 1993, "Misce11aneous Streams P1 an and Schedule" (Letter 9401521 to D. Ny Tander, Washington State Department of Ecology, Olympia, Washington, January 31, 1994), U.S. Department of Energy, Richland Operations Office, Richland, Washington.

Holmes, J.J., 1994, Systems Engineering Functions and Requirements for the Hanford Cleanup Mission: First Issue, WHC-EP-0722, Westinghouse Hanford Company, Richland, Washington. 
Jackson, G.W., 1994, "Transmittal of the Draft Hanford Site Systems Engineering Manual" (Letter 9455534 to W.A. Rutherford, U.S. Department of Energy, Richland Operations Office, Richland, Washington, August 12, 1994), Westinghouse Hanford Company, Richland, Washington.

RL, 1987, P7an and Schedule to Discontinue Disposal of Contaminated Liquids into the Soil Column at the Hanford Site, DOE-065, Response to Congressional Request, U.S. Department of Energy, Richland Operations office, Richland, Washington.

$\mathrm{RL}, 1994 \mathrm{a}, \mathrm{P} 7 \mathrm{an}$ and Schedule for Disposition and Regulatory Compliance for Miscellaneous Streams, DOE/RL-93-94, U.S. Department of Energy, Rich7and Operations Office, Richland, Washington.

$\mathrm{RL}$, 1994b, Fisca7 Year 1995 Hanford Mission P7an, DOE/RL-93-102, Draft (JuTy 1994), U.S. Department of Energy, Richland Operations Office, Richiand, Washington.

Stordeur, R.T. and D.L. Flyckt, 1988, Annual Status Report of the P7an and Schedule to Discontinue Disposal of Contaminated Liquids into the Soil Column at the Hanford Site, WHC-EP-0196-1, Westinghouse Hanford Company, Richland, Washington.

WHC, 1990, Hanford Site Stream-Specific Reports, WHC-EP-0342, Westinghouse Hanford Company, Richland, Washington.

WHC, 1993, Hanford Site Solid Waste Acceptance Criteria, WHC-EP-0063-4, Westinghouse Hanford Company, Richland, Washington.

WHC, 1994, Liquid Effluent Annual Report, WHC-EP-TBD, Westinghouse Hanford Company, Richland, Washington. 
WHC-SD-WM-MAR-003 Rev. 0

APPENDIX A

PROJECTS IN THE LIQUID EFFLUENTS PROGRAM

A-1 
WHC-SD-WM-MAR-003 Rev. 0

This page intentionally left blank. 
Table A-1. 200 Area Effluent Treatment Facility, Project C-018H.

Project Description: The double-she11 tanks (DSTs) contain 1isted wastes as defined by RCRA. These wastes are processed in the 242-A Evaporator to produce a concentrated waste which is returned to the DSTs, and a process condensate stream. The process condensate is a listed waste via the "derived from" rule and must be managed in accordance with RCRA. High concentrations of ammonia in the process condensate also make this stream a dangerous waste subject to WAC 173-303 requiremenț. Available storage space in the DSTs to support remediation of the tank waste and cleanup of the Hanford Site is Timited. Effluent treatment and disposal capability is needed to support the continued operation of the 242-A Evaporator.

The 200 Area ETF will provide (1) collection of effluents, (2) treatment to reduce the concentration of radioactive and hazardous waste constituents to acceptable levels, (3) verification prior to discharge, and (4) discharge to the State-Approved Land Disposal Structure (SALDS). Secondary waste from treating the process condensate is a low-level mixed waste that will be concentrated, dried, packaged, and transferred to WRAP Module 2A (Project $W-100$ ) for subsequent treatment and disposal. Treatment capacity of the 200 Area ETF is $570 \mathrm{~L} / \mathrm{min}(150 \mathrm{gal} / \mathrm{min})$.

Project Status: Construction is approximately $90 \%$ complete. Startup is scheduled for June 1995 but will likely be delayed.

Project Documents

\begin{tabular}{|c|c|}
\hline $\begin{array}{l}\text { Engineering } \\
\text { Studies }\end{array}$ & $\begin{array}{l}\text { McDonald, F.N., 1992, Project C-018H Waste Water } \\
\text { Engineering A7ternatives Treatment Report, } \\
\text { WHC-SD-CO18H-ER-001, Revision 1, Westinghouse Hanford } \\
\text { Company, Richland, Washington. }\end{array}$ \\
\hline Design Criteria & $\begin{array}{l}\text { Flyckt, D.L., 1990, Functional Design Criteria for the } \\
242-A \text { Evaporator/PUREX Plant Condensate Treatment } \\
\text { Facility, WHC-SD-CO18-FDC-001, Revision 2, Westinghouse } \\
\text { Hanford Company, Richland, Washington. } \\
\text { Ke17y, J.W., 1993, Design Construction Specification } \\
\text { Project C-OI8H 242-A Evaporator/PUREX P7ant Process } \\
\text { Condensate Treatment Facility, V-CO18HC1-001, } \\
\text { Revision OE, Westinghouse Hanford Company, Richland, } \\
\text { Washington. }\end{array}$ \\
\hline Design Reports & TBD \\
\hline
\end{tabular}


Table A-1. 200 Area Effluent Treatment Facility, Project C-018H (cont'd).

\begin{tabular}{|c|c|}
\hline Permits & 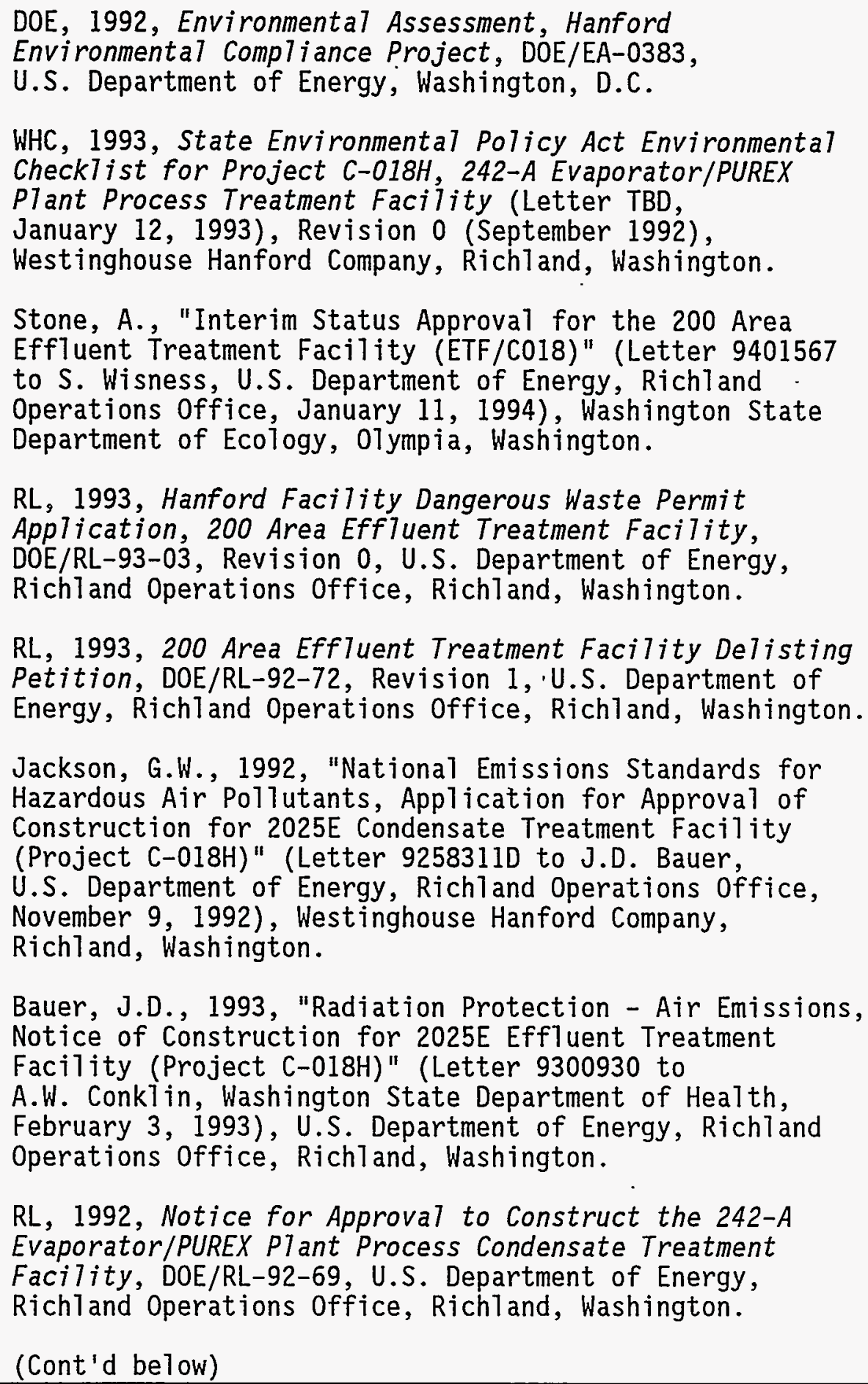 \\
\hline
\end{tabular}


WHC-SD-WM-MAR-003 Rev. 0

Table A-1. 200 Area Effluent Treatment Facility, Project C-018H (cont'd).

\begin{tabular}{|c|c|}
\hline $\begin{array}{l}\text { Permits } \\
\text { (cont'd) }\end{array}$ & 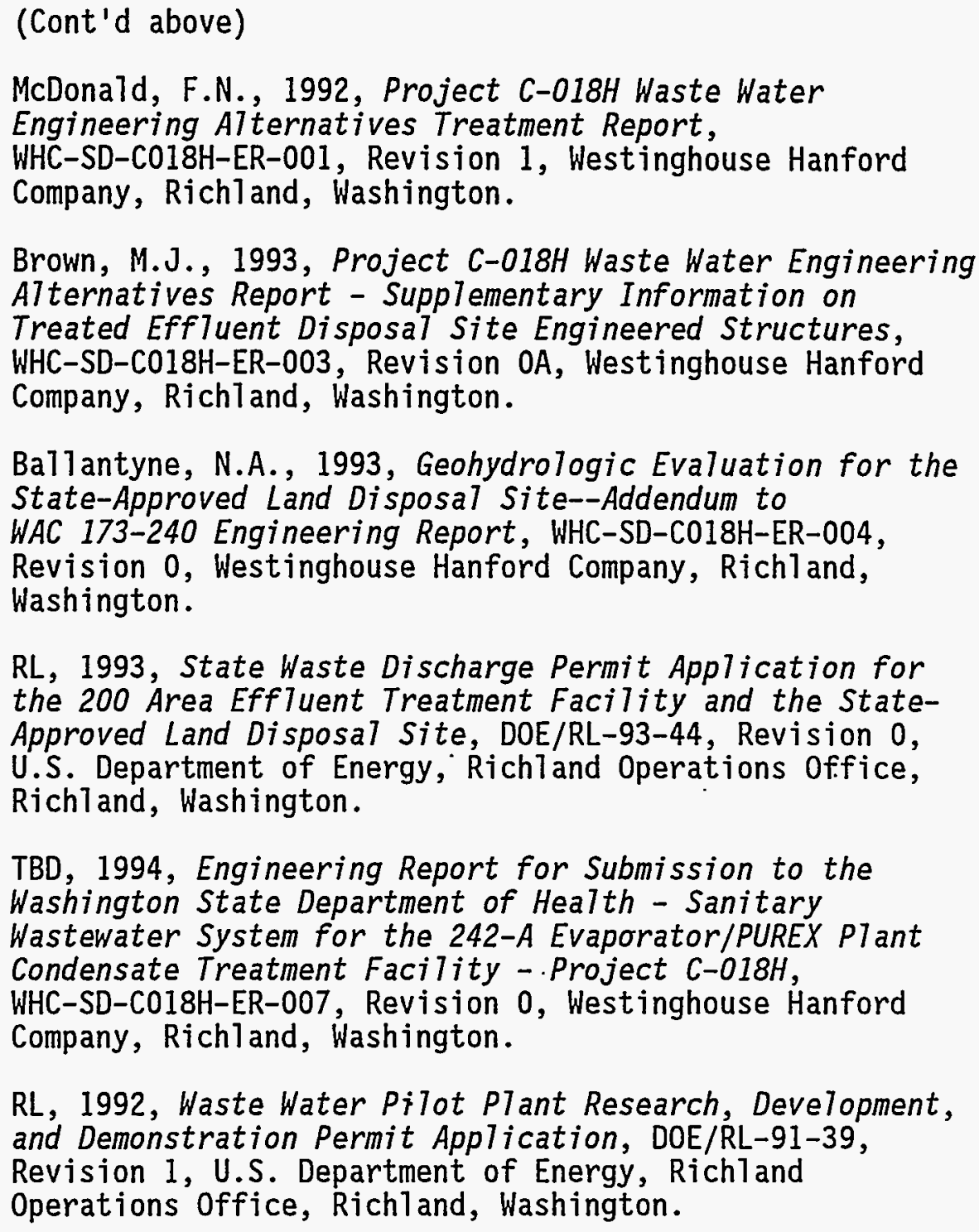 \\
\hline Safety Analyses & $\begin{array}{l}\text { Lavender, J.C., 1993, Preliminary Safety Analysis Report } \\
\text { for Project C-O18H, 242-A EVaporator/PUREX Plant } \\
\text { Condensate Treatment Facility, WHC-SD-CO18H-PSAR-001, } \\
\text { Revision 0, Westinghouse Hanford Company, Richland, } \\
\text { Washington. }\end{array}$ \\
\hline $\begin{array}{l}\text { Other Relevant } \\
\text { Documents }\end{array}$ & TBD \\
\hline
\end{tabular}


WHC-SD-WM-MAR-003 Rev. 0

Table A-2. 200 Area Treated Effluent Disposal Facility, Project $\mathrm{W}-049 \mathrm{H}$ :

Project Description: The 200 Area TEDF is a collection system for transporting Phase I and II waste streams meeting BAT/AKART requirements to a single permitted soil column disposal site. Each facility connected to the system must comply with Timits stipulated in the WAC 173-216 permit for discharging to the soil column without further treatment. No provisions exist within the 200 Area TEDF to mitigate contamination once it enters the collection system. Implementation of BAT/AKART at each facility is the responsibility of the generating facilities and is being integrated with the completion of Project $W-049 H$. Waste Certification Plans have been developed which define the criteria each stream must meet prior to discharging to the 200 Area TEDF.

Project Status: Construction is approximately $98 \%$ complete. Startup is scheduled for June 1995.

Project Documents

\begin{tabular}{|c|c|}
\hline $\begin{array}{l}\text { Engineering } \\
\text { Studies }\end{array}$ & $\begin{array}{l}\text { Carrigan, M.C., 1991, Engineering Study to Evaluate Need } \\
\text { for Modifications to Liquid Effluent Retention Facility- } \\
\text { LERF Basin Design, WHC-SD-W049H-ES-001, Revision 0, } \\
\text { Westinghouse Hanford Company, Richland, Washington. } \\
\text { Carrigan, M.C., 1991, Final Letter Report } 200 \text { West Area } \\
\text { Effluent Collection System Project W-049H, } \\
\text { WHC-SD-W049H-ES-002, Revision 0, Westinghouse Hanford } \\
\text { Company, Richland, Washington. } \\
\text { Davis, J.D., 1992, Project W-049H Treated Effluent } \\
\text { disposa7 A7ternatives Engineering Study, } \\
\text { WHC-SD-W049H-ES-003, Revision OA, Westinghouse Hanford } \\
\text { Company, Richland, Washington. }\end{array}$ \\
\hline Design Criteria & $\begin{array}{l}\text { WHC, 1994, Functional Design Criteria for the } 200 \text { Area } \\
\text { Treated Effluent Disposal Facility, Project W-049H, } \\
\text { WHC-SD-W049H-FDC-001, Revision 1B, Westinghouse Hanford } \\
\text { Company, Richland, Washington. } \\
\text { Carrigan, M.C:, 1992, Letter Report Requirements for } \\
\text { Reuse of Liquid Effluent Retention Facility LERF Basins, } \\
\text { Project W-O49H, WHC-SD-W049H-ES-004, Revision 0, } \\
\text { Westinghouse Hanford Company, Richland, Washington. } \\
\text { (Cont'd below) }\end{array}$ \\
\hline
\end{tabular}


Table A-2. 200 Area Treated Effluent Disposal Facility, Project $W-049 H$ (cont'd).

\begin{tabular}{|c|c|}
\hline $\begin{array}{l}\text { Design Criteria } \\
\text { (cont'd) }\end{array}$ & $\begin{array}{l}\text { (Cont'd above) } \\
\text { Carrigan, M.C., 1992, Supplemental Design Requirements } \\
\text { Document for the } 200 \text { Area Treated Effluent Disposal } \\
\text { Facility Project W-049H, WHC-SD-WO49H-SDRD-001, } \\
\text { Revision 0, Westinghouse Hanford Company, Richland, } \\
\text { Washington. } \\
\text { Crane, A.F., 1992, Supplemental Design Requirements } \\
\text { Document for the } 200 \text { Area Treated Effluent Disposal } \\
\text { Facility Project W-049H, WHC-SD-WO49H-SDRD-002, } \\
\text { Revision 0, Westinghouse Hanford Company, Richland, } \\
\text { Washington. }\end{array}$ \\
\hline Design Reports & $\begin{array}{l}\text { Carrigan, M.C., 1993, Conceptual Design Report } 200 \text { Area } \\
\text { Treated Effluent Disposa7 Facility Project W-049H, } \\
\text { WHC-SD-W049H-CDR-002, Revision 2, Westinghouse Hanford } \\
\text { Company, Richland, Washington. } \\
\text { Carrigan, M.C., 1992, Letter Report } 200 \text { Area Treated } \\
\text { Effluent Disposa7 Facility Phase II Advanced Conceptual } \\
\text { Design, Optimization of Pipe7ine, Project W-049H, } \\
\text { WHC-SD-W049H-ES-006, Revision 0, Westinghouse Hanford } \\
\text { Company, Rich7and, Washington. } \\
\text { Brown, M.J., 1993, } 200 \text { Area Treated Effluent Disposal } \\
\text { Facility Project W-049H Wastewater Engineering Report, } \\
\text { WHC-SD-W049H-ER-003, Revision OC, Westinghouse Hanford } \\
\text { Company, Richland, Washington. }\end{array}$ \\
\hline Permits & $\begin{array}{l}\text { DOE, 1992, Environmental Assessment, Hanford } \\
\text { Environmental Compliance Project, DOE/EA-0383, } \\
\text { U.S. Department of Energy, Washington, D.C. } \\
\text { SEPA Checklist - TBD } \\
\text { RL, 1994, State Waste Discharge Permit Application } \\
200 \text { Area Treated Effluent Disposal Facility } \\
\text { (Project W-049H), DOE/RL-94-29, Draft, U.S. Department of } \\
\text { Energy, Richland Operations Office, Richland, Washington. } \\
\text { CAA RAEP - TBD } \\
\text { (Cont'd below) }\end{array}$ \\
\hline
\end{tabular}


Table A-2. 200 Area Treated Effluent Disposal Facility, Project $\mathrm{W}-\mathrm{O} 49 \mathrm{H}$ (cont'd).

\begin{tabular}{|c|c|}
\hline $\begin{array}{l}\text { Permits } \\
\text { (cont'd) }\end{array}$ & $\begin{array}{l}\text { (Cont'd above) } \\
\text { Brown, M.J. and A.F. Crane, 1992, } 200 \text { Area Treated } \\
\text { Effluent Disposal Facility (Project W-049H) Wastewater } \\
\text { Engineering Report, WHC-SD-W049H-ER-003, Revision 1, } \\
\text { Westinghouse Hanford Company, Richland, Washington. } \\
\text { RL, 1994, State Waste Discharge Permit Application } \\
200 \text { Area Treated Effluent Disposal Facility } \\
\text { (Project W-049H), DOE/RL-94-29, Draft, U.S. Department of } \\
\text { Energy, Richland Operations Office, Richland, Washington. }\end{array}$ \\
\hline Safety Analyses & $\begin{array}{l}\text { Lavender, J.C., 1990, Preliminary Safety Evaluation } \\
200 \text { Area Treated Effluent Disposal Facility, } \\
\text { WHC-SD-W049H-PSE-001, Revision 0, Westinghouse Hanford } \\
\text { Company, Richland, Washington. } \\
\text { Johnson, H.E., 1993, Hazard Classification Analysis, } \\
\text { WHC-SD-W049H-HC-001, Revision 0, Westinghouse Hanford } \\
\text { Company, Richland, Washington. } \\
\text { Dale, J.S., 1993, Fire Hazard Analysis for the } 200 \text { Area } \\
\text { Treated Effluent Disposal Facility, WHC-SD-W049H-HIE-001, } \\
\text { Revision 0, Westinghouse Hanford Company, Richland, } \\
\text { Washington. }\end{array}$ \\
\hline $\begin{array}{l}\text { Other Relevant } \\
\text { Documents }\end{array}$ & $\begin{array}{l}\text { Benton, J.B., 1992, Project W-O49H Interface Contro7 } \\
\text { Document, WHC-SD-W049H-ICD-001, Revision 0, Westinghouse } \\
\text { Hanford Company, Richland, Washington. } \\
\text { Arntzen, M.C., 1992, Project Specific Quality Assurance } \\
\text { P7an Project W-049H } 200 \text { Area Treated Effluent Disposa } \\
\text { Facility, WHC-SD-W049H-QAPP-001, Revision 0, Westinghouse } \\
\text { Hanford Company, Richland, Washington. }\end{array}$ \\
\hline
\end{tabular}


Table A-3. 300 Area Treated Effluent Disposal Facility, Project L-045H.

Project Description: Process wastewaters from the 300 Area have historically been discharged to trenches for disposal by percolation. The wastewater originates as liquid effluents from laboratories, research facilities, office buildings, and fuel fabrication facilities. The stream consists of once-through cooling water, steam condensate, and other liquid wastes generated in non-contact radioactive processes.

The 300 Area TEDF is being constructed to treat the 300 Area Process Sewer and Retention Process Sewer wastewater which meets acceptance criteria.

The facility is designed to treat the wastewater using BAT. The treatment process includes iron co-precipitation to remove heavy metals, thiol

functional resin ion exchange to remove mercury, and ultraviolet light/hydrogen peroxide oxidation to destroy organics and cyanide. Sludge from the iron co-precipitation process is (1ikely) a low-level waste and will be dewatered and disposed of in the Low-Level Waste Burial Grounds. Spent ion exchange resin is a low-level mixed waste that will be transferred to the Central Waste Complex. The treated liquid effluent will be monitored and discharged through an outfall to the Columbia River.

Project Status: Construction was completed in July 1994. Startup is scheduled for December 1994.

Project Documents

Engineering Studies
Beck, R.W., 1990, 300 Area Sanitary and Process Wastewater Study, R.W. Beck and Associates for the City of Richland, Washington.

CH2M Hi11, 1993, Engineering Summary Report - Hanford 300 Area Process Wastewater Discharge to the City of Richland POTW, CH2M Hill, Inc., Richland, Washington.

CH2M Hil1, 1993, Hanford 300 Area--Addendum Engineering Summary Report, $\mathrm{CH} 2 \mathrm{M} H \mathrm{H} 11$, Inc., Richland, Washington.

01 ander, A.R., 1993, Value Engineering L-045 vs City of Richland Discharge Approach Final Report, WHC-SD-L045H-VES-001, Revision 0, Westinghouse Hanford Company, Richland, Washington.

Stordeur, R.T., 1992, Functional Design Criteria for the 300 Area Treated Effluent Disposal Facility, WHC-SD-L045H-FDC-001, Revision 1, Westinghouse Hanford Company, Richland, Washington. 
Table A-3. 300 Area Treated Effluent Disposal Facility, Project L-045H (cont'd).

\begin{tabular}{|c|c|}
\hline Design Reports & $\begin{array}{l}\text { Carrigan, M.C., 1990, Conceptual Design Report, } 300 \text { Area } \\
\text { Treated Effluent Disposal Facility, Project } 92 L-G F L-045 H \text {, } \\
\text { WHC-SD-LO45H-CDR-001, Revision 0, Westinghouse Hanford } \\
\text { Company, Richland, Washington. } \\
\text { CH2M Hi17, 1993, Predesign Package Submittal Hanford } \\
300 \text { Area Process Wastewater Discharge to the City of } \\
\text { Richland POTW, CH2M Hill, Inc., Richland, Washington. }\end{array}$ \\
\hline Permits & $\begin{array}{l}\text { DOE, 1992, Environmental Assessment, Hanford } \\
\text { Environmental Compliance Project, DOE/EA-0383, } \\
\text { U.S. Department of Energy, Washington, D.C. } \\
\text { WHC, 1992, State Environmental Policy Act Environmenta7 } \\
\text { Checklist for Project L-045H, 300 Area Treated Effluent } \\
\text { Disposal Facility (Letter TBD), Revision O (November } \\
\text { 1992), Westinghouse Hanford Company, Richland, } \\
\text { Washington. } \\
\text { Stordeur, R.T., 1992, Hanford 300 Area Treated Effluent } \\
\text { Disposa7 Facility Engineering Summary Report, } \\
\text { WHC-SD-LO45H-ER-002, Revision 0, Westinghouse Hanford } \\
\text { Company, Richland, Washington. } \\
\text { Jackson, G.W., 1993, "NESHAPS Application for Approval of } \\
\text { Construction for the 300 Area TEDF" (Letter 9350665D to } \\
\text { J.D. Bauer, U.S. Department of Energy, Richland } \\
\text { Operations Office, Richland, Washington, January 27, } \\
\text { l993), Westinghouse Hanford Company, Richland, } \\
\text { Washington. } \\
\text { Bauer, J.D., 1992, "WAC 246-247 Notice of Construction } \\
\text { for the 300 Area Treated Effluent Disposal Facility" } \\
\text { (Letter 9207203 to TBD, Washington State Department of } \\
\text { Health, Olympia, Washington, October 13, 1992), } \\
\text { U.S. Department of Energy, Richland Operations office, } \\
\text { Richland, Washington. } \\
\text { CWA NPDES - TBD } \\
\text { Wild and Scenic Rivers - TBD } \\
\text { Hydraulic Permit - TBD } \\
\text { (Cont'd below) }\end{array}$ \\
\hline
\end{tabular}


Table A-3. 300 Area Treated Effluent Disposal Facility, Project L-045H (cont'd).

\begin{tabular}{|c|c|}
\hline $\begin{array}{l}\text { Permits } \\
\text { (cont'd) }\end{array}$ & $\begin{array}{l}\text { (Cont'd above) } \\
\text { Bauer, J.D., 1993, "U.S. Army Corps of Engineers Section } \\
404 \text { Permit - Hanford } 300 \text { Area Treated Effluent Disposal } \\
\text { Facility" (Letter } 9300970 \text { to A. Winther, U.S. Army Corps } \\
\text { of Engineers, Seattle, Washington, Apri1 30, 1993), } \\
\text { U.S. Department of Energy, Richland Operations Office, } \\
\text { Richland, Washington. } \\
\text { Water Quality Mod. - TBD } \\
\text { Mark, T. 1993, "Benton County Permit \#CUp93-1 } \\
\text { Application for Shore1 ine Substantial Development Permit/ } \\
\text { Conditional Use Permit \#1993-14842" (Letter 9307048 to } \\
\text { T.A. Mardin, Benton County, and.J.E. Turnbaugh, } \\
\text { Westinghouse Hanford Company, Richland, Washington, } \\
\text { August 23, 1993), Washington State Department of Ecology, } \\
\text { 01ympia, Washington. }\end{array}$ \\
\hline Safety Analyses & $\begin{array}{l}\text { Eacker, J.A., 1993, Hanford } 300 \text { Area Treated Effluent } \\
\text { Disposal Facility - Inventory at Risk Calculations and } \\
\text { Safety Analysis, WHC-SD-WM-SAD-025, Revision 1, } \\
\text { Westinghouse Hanford Company, Richland, Washington. } \\
\text { Van Vleet, R.J., 1990, Preliminary Safety Evaluation for } \\
300 \text { Area Treated Effluent Disposal Facility, } \\
\text { Project L-O45H, WHC-SD-L045H-PSE-001, Revision 0, } \\
\text { Westinghouse Hanford Company, Richland, Washington. } \\
\text { Bendixsen, R.B., 1993, } 300 \text { Area Treated Effluent Disposal } \\
\text { Facility (TEDF) Preliminary Safety Analysis Document } \\
\text { (PSAD), WHC-SD-LO45H-SAD-001, Revision 0, Westinghouse } \\
\text { Hanford Company, Richland, Washington. } \\
\text { Bendixsen, R.B., 1994, 300 Area TEDF, Process Information } \\
\text { and Hazards Analysis, WHC-SD-LO45H-SAR-001, Revision OA, } \\
\text { Westinghouse Hanford Company, Richland, Washington. }\end{array}$ \\
\hline $\begin{array}{l}\text { Other Relevant } \\
\text { Documents }\end{array}$ & $\begin{array}{l}\text { WHC, 1993, Facility Description Manual: Hanford } 300 \text { Area } \\
\text { Treated Effluent Disposal Facility, (CH2M Hill, Inc. for) } \\
\text { Westinghouse Hanford Company, Richland, Washington. } \\
\text { (Cont'd below) }\end{array}$ \\
\hline
\end{tabular}


Table A-3. 300 Area Treated Effluent Disposal Facility, Project L-045H (cont'd).

\begin{tabular}{|l|l|}
\hline $\begin{array}{l}\text { Other Relevant } \\
\text { Documents } \\
\text { (cont'd) }\end{array}$ & $\begin{array}{l}\text { (Cont'd above) } \\
\text { Draper, T.N., 1993, 300 Area Utilities and Effluent } \\
\text { Treatment Processing Administration Policy Manual, } \\
\text { WHC-IP-384, Revision 0, Westinghouse Hanford Company, } \\
\text { Richland, Washington. [Includes Section SWU3-0-TEDF-1, } \\
\text { "Process Sewer and Retention Process Sewer Volume and } \\
\text { Flow Control;" Section SWU3-0-TEDF-2, "Waste Acceptance } \\
\text { Criteria for the 300 Area Process Sewer and the Treated } \\
\text { Effluent Disposal Facil ity;" and Section SWU3-0-TEDF-3, } \\
\text { "300 Area Process Sewer and Retention Process Sewer } \\
\text { Liquid Waste Certification Program."] }\end{array}$ \\
\hline
\end{tabular}


Table A-4. Phase II Liquid Effluent Treatment and Disposal, Project $W-252$.

Project Description: Project $W-252$ provides BAT/AKART treatment for some Phase II waste streams. Those streams located in the 200 Area are planned to discharge to the 200 Area TEDF after BAT/AKART is implemented. A single waste stream located in the 400 Area will be handled independently.

Project Status: Project is in Advanced Conceptual Design. Definitive Design is scheduled to start in January 1995.

Project Documents

\begin{tabular}{|c|c|}
\hline $\begin{array}{l}\text { Engineering } \\
\text { Studies }\end{array}$ & TBD \\
\hline Design Criteria & $\begin{array}{l}\text { Halgren, D.L., 1992, Functional Design Criteria for } \\
\text { Project W-252, Phase II Liquid Effluent Treatment and } \\
\text { Disposal, WHC-SD-W252-FDC-001, Revision 0, Westinghouse } \\
\text { Hanford Company, Richland, Washington. }\end{array}$ \\
\hline Design Reports & $\begin{array}{l}\text { Sato, P.K., 1993, Conceptual Design Report for } \\
\text { Project W-252, Phase II Liquid Effluent Treatment and } \\
\text { Disposal, WHC-SD-W252-CDR-001, Revision 0, Westinghouse } \\
\text { Hanford Company, Richland, Washington. }\end{array}$ \\
\hline Permits & $\begin{array}{l}\text { NEPA Categorical Exclusion - TBD } \\
\text { DiLiberto, A.J., 1994, "State Environmental Policy Act } \\
\text { (SEPA) Checklist for the Other Phase II Liquid Effluent } \\
\text { Streams (Project W-252)" (Letter 9451425D to J.M. Hennig, } \\
\text { U.S. Department of Energy, Richland Operations Office, } \\
\text { Richland, Washington, March 17, 1994), Westinghouse } \\
\text { Hanford Company, Richland, Washington. } \\
\text { Halgren, D.L. and J.D. Williams, 1992, Phase II Liquid } \\
\text { Effluent Program (Project W-252) Wastewater Engineering } \\
\text { Report and BAT/AKART Studies, WHC-SD-W252-ER-001, } \\
\text { Revision 0, Westinghouse Hanford Company, Richland, } \\
\text { Washington. } \\
\text { RL, 93, State Waste Discharge Permit Application - } \\
200 . \text { East Area W-252 Streams, DOE/RL-93-61, Revision 0, } \\
\text { U.S. Department of Energy, Richland Operations Office, } \\
\text { Richland, Washington. }\end{array}$ \\
\hline
\end{tabular}


Table A-4. Phase II Liquid Effluent Treatment and Disposal, Project W-252 (cont'd).

\begin{tabular}{|l|l|}
\hline Safety Analyses & $\begin{array}{l}\text { Bendixsen, R.B., 1993, Prel iminary Safety Evaluation } \\
\text { (PSE) for Project W-252, Phase II Liquid Effluent } \\
\text { Treatment and Disposa7, WHC-SD-W252-PSE-001, Revision 0, } \\
\text { Westinghouse Hanford Company, Richland, Washington. }\end{array}$ \\
\hline $\begin{array}{l}\text { Other Relevant } \\
\text { Documents }\end{array}$ & $\begin{array}{l}\text { Arntzen, M.C., 1993, Project-Specific Quality Assurance } \\
\text { P7an, Phase II Liquid Effluent Treatment and Disposa7, } \\
\text { WHC-SD-W252-QAPP-001, Revision 0, Westinghouse Hanford } \\
\text { Company, Richland, Washington. }\end{array}$ \\
\hline
\end{tabular}


Table A-5. 200 Area Effluent BAT/AKART Implementation, Project $W-291$.

Project Description: Project $W-291 \mathrm{H}$ provides BAT/AKART treatment for some Phase I and II waste streams that could otherwise not realistically expect to be funded in time to meet applicable Tri-Party Agreement milestones. These streams are a71 Tocated in the 200 Area and are planned to discharge to the 200 Area TEDF after BAT/AKART is implemented.

Project Status: Construction was recently begun and is scheduled to be complete in June 1995.

Project Documents

\begin{tabular}{|l|l|}
\hline $\begin{array}{l}\text { Engineering } \\
\text { Studies }\end{array}$ & TBD \\
\hline Design Criteria & $\begin{array}{l}\text { Brown, M.J., 1994, Functional Design Criteria for } \\
\text { Project W-291 200 Area BAT/AKART Implementation, } \\
\text { WHC-SD-W291H-FDC-001, Revision 1, Westinghouse Hanford } \\
\text { Company, Richland, Washington. }\end{array}$ \\
\hline Design Reports & $\begin{array}{l}\text { Pedersen, K.S., 1993, Conceptual Design Report for } \\
\text { Project W-291, 200 Area BAT/AKART Implementation, } \\
\text { WHC-SD-W291-CDR-001, Revision 0, Westinghouse Hanford } \\
\text { Company, Richland, Washington. }\end{array}$ \\
\hline Permits & $\begin{array}{l}\text { Wagoner, J.D., 1993, "National Environmental Policy Act } \\
\text { Categorica1 Determination: Project W-291, Implementation } \\
\text { of the Best Available Technology Economically Achievable } \\
\text { for the Treated Effluent Disposal Facility, 200 Area, } \\
\text { Hanford Site, Richland, Washington" (Letter 9302125 to } \\
\text { C.M.Bergstrom, U.S. Department of Energy, Headquarters, } \\
\text { Washington, D.C., February 23, 1993), U.S. Department of } \\
\text { Energy, Richland Operations Office, Richland, Washington. } \\
\text { SEPA CheckTist - Not required. } \\
\text { Pedersen, K.S., 1992, Project W-291, Engineering Report } \\
\text { for 200 Areas Effluent BAT/AKART Implementation, } \\
\text { WHC-SD-W291-ER-001, Revision 0, Westinghouse Hanford } \\
\text { Company, Richland, Washington. }\end{array}$ \\
\hline
\end{tabular}




$$
\text { WHC-SD-WM-MAR-003 Rev. } 0
$$

Table A-5. 200 Area Effluent BAT/AKART Implementation, Project W-291 (cont'd).

\begin{tabular}{|l|l|}
\hline Safety Analyses & $\begin{array}{l}\text { Lavender, J.C., 1993, Prel iminary Safety Evaluation for } \\
\text { Project W-291, 200 Areas Effluent BAT/AKART } \\
\text { Implementation, WHC-SD-W291-PSE-001, Revision 0, } \\
\text { Westinghouse Hanford Company, Richland, Washington. } \\
\text { Bendixsen, R.B., 1994, } 200 \text { Areas Effluent BAT/AKART } \\
\text { Implementation, Pre7 iminary Safety Analysis Report, } \\
\text { WHC-SD-W291H-PSAR-001, Revision 0, Westinghouse Hanford } \\
\text { Company, Richland, Washington. }\end{array}$ \\
\hline $\begin{array}{l}\text { Other Relevant } \\
\text { Documents }\end{array}$ & $\begin{array}{l}\text { Pedersen, K.S., 1993, 200 Areas Effluent BAT/AKART } \\
\text { Implementation Project-Specific Qua7 ity Assurance Plan } \\
\text { Project W-291, WHC-SD-W291-QAPP-001, Revision 0, } \\
\text { Westinghouse Hanford Company, Richland, Washington. }\end{array}$ \\
\hline
\end{tabular}


Table A-6. Liquid Effluent Retention Facility, Project W-105.

Project Description: The LERF consists of three basins for temporarily storing process condensate from the 242-A Evaporator while awaiting treatment in the 200 Area ETF. A fourth basin wass excavated but never completed. Each basin has a capacity of $24,600 \mathrm{~m}^{3}$ (6.5 million gallons) and measures $101 \mathrm{~m}(330 \mathrm{ft})$ by $82 \mathrm{~m}(270 \mathrm{ft})$, with a maximum liquid depth of $5.8 \mathrm{~m}(19 \mathrm{ft})$ and a minimum freeboard of $1.5 \mathrm{~m}(5 \mathrm{ft})$; the basins are arranged side by side and spaced $18 \mathrm{~m}(60 \mathrm{ft})$ apart. The basins are constructed of a primary liner of 1.5-mm (60-mi1) thickness high-density polyethylene, over a secondary liner consisting of a manufactured geotextile/bentonite carpet layer with a hydraulic conductivity less than $10^{-7} \mathrm{~cm} / \mathrm{s}$. A system is provided to detect, collect, and remove leachate from between the primary and secondary liners. A floating geomembrane cover of $1.5-\mathrm{mm}(60-\mathrm{mi} 7)$ very low-density polyethylene is stretched over each basin to keep unwanted material from entering the basins and to minimize evaporation of the basin contents. The LERF is to cease operation by December 1994, and the hazardous residues (if any) are to be removed by June 1995. Continued use of the LERF basins is being explored.

Project Status: Construction is complete. Two basins began operation in April 1994; operational testing of the remaining basin will be complete in october 1994.

Project Documents

\begin{tabular}{|l|l|}
\hline $\begin{array}{l}\text { Engineering } \\
\text { Studies }\end{array}$ & TBD \\
\hline Design Criteria & $\begin{array}{l}\text { 01ascoaga, M.A., 1991, Functional Design Criteria for the } \\
\text { Liquid Effluent Retention Facility 242-A Evaporator } \\
\text { Condensate Interim Retention Basins, WHC-SD-W105-FDC-001, } \\
\text { Revision 1, Westinghouse Hanford Company, Richland, } \\
\text { Washington. }\end{array}$ \\
\hline Design Reports & $\begin{array}{l}\text { Tol1bom, L.R., 1991, System Design Description 242-A } \\
\text { Evaporator Condensate Interim Retention Basins } \\
\text { Project W-105, WHC-SD-W105-SDD-001, Revision 0, } \\
\text { Westinghouse Hanford Company, Rich1 and, Washington. } \\
\text { Hal1um, R.T., 1991, System Design Intent for } \\
\text { 242-A Evaporator Condensate Interim Retention Basins } \\
\text { Project W-105, WHC-SD-W105-SDI-001, Revision 0, } \\
\text { ICF Kaiser Hanford Company, Rich1 and, Washington. }\end{array}$ \\
\hline
\end{tabular}


WHC-SD-WM-MAR-003 Rev. 0

Table A-6. Liquid Effluent Retention Facility, Project W-105 (cont'd).

\begin{tabular}{|c|c|}
\hline Permits & $\begin{array}{l}\text { SEPA Checklist - TBD } \\
\text { RCRA Interim Status - TBD } \\
\text { RCRA Parts A, B - TBD } \\
\text { RL, 1991, Liquid Effluent Retention Facility Dangerous } \\
\text { Waste Permit Application, DOE/RL-90-43, Revision 0, } \\
\text { U.S. Department of Energy, Richland Operations Office, } \\
\text { Richland, Washington. } \\
\text { Wisness, S.H., 1994, "State Waste Discharge Permit } \\
\text { Application for One Time/Limited Duration Discharges to } \\
\text { Ground" (Letter 94-RPS-278 to D.C. Nylander, Washington } \\
\text { State Department of Ecology, OTympia, Washington, } \\
\text { July 19, 1994), U.S. Department of Energy, Richland } \\
\text { Operations Office, Richland, Washington. }\end{array}$ \\
\hline Safety AnaTyses & $\begin{array}{l}\text { Lavender, J.C., 1993, Final Safety Analysis Report } 242-A \\
\text { Evaporator Liquid Effluent Retention Faci7ity, } \\
\text { WHC-SD-W105-SAR-001, Revision OC, Westinghouse Hanford } \\
\text { Company, Rich7and, Washington. }\end{array}$ \\
\hline $\begin{array}{l}\text { Other Relevant } \\
\text { Documents }\end{array}$ & $\begin{array}{l}\text { Ha11, L.R., 1990, Project Specific Quality Assurance Plan } \\
\text { for the } 242-A \text { EVaporator and PUREX Interim Retention } \\
\text { Basin (Project W-105), WHC-SD-W105-QAPP-001, Revision OA, } \\
\text { Westinghouse Hanford Company, Richland, Washington. }\end{array}$ \\
\hline
\end{tabular}


Table A-7. 340 Facility Secondary Containment and Leak Detection, Project W-302.

Project Description: The 340 Facility provides interim storage and transfer capability for waste generators in the 300 Area. Sources of the waste include laboratories and research facilities connected to the radioactive liquid waste system (RLWS) and the retention process sewer (RPS). The RLWS collects wastes known to be radioactively-contaminated. The RPS collects wastes which may become contaminated during abnormal or upset conditions. Containerized wastes are also discharged to the RLWS at the 340 Facility. The waste is accumulated in tanks and periodically transferred by rail car to the 204-AR Waste Unloading Facility for eventual storage in DSTs. A tanker truck load-out facility is also provided in the 340 Facility.

Project W-302 will provide upgrades to the 340 Facility to allow RCRAcompliant storage of mixed wastes for more than 90 days. New tanks and vaults are being provided, with connecting piping to the existing facility.

Project Status: Functional design criteria document is nearly complete. Conceptual design is expected to start October 1994.

Project Documents

\begin{tabular}{|c|c|}
\hline $\begin{array}{l}\text { Engineering } \\
\text { Studies }\end{array}$ & $\begin{array}{l}\text { Stordeur, R.T., 1994, Engineering Study of the } 300 \text { Area } \\
\text { Process Wastewater Hand7ing System, WHC-SD-WM-ER-277, } \\
\text { Revision 0, Westinghouse Hanford Company, Richland, } \\
\text { Washington. }\end{array}$ \\
\hline Design Criteria & $\begin{array}{l}\text { Stordeur, R.T., 1994, Functional Design Criteria for the } \\
340 \text { Radioactive Liquid Waste Storage Facility Upgrade: } \\
\text { Project W-302, WHC-SD-W302-FDC-001, Draft (September } \\
\text { 1994), Westinghouse Hanford Company, Richland, } \\
\text { Washington. }\end{array}$ \\
\hline Design Reports & TBD \\
\hline Permits & TBD \\
\hline Safety Analyses & TBD \\
\hline $\begin{array}{l}\text { Other Relevant } \\
\text { Documents }\end{array}$ & $\begin{array}{l}\text { Berneski, L.D., 1993, Technical Requirements for Use of } \\
\text { the RLWS and RPS, WHC-SD-WM-TI-468, Revision } 2 \text {, } \\
\text { Westinghouse Hanford Company, Richland, Washington. }\end{array}$ \\
\hline
\end{tabular}


Table A-8. 300 Area Retention Process Sewer Monitoring/Diversion Upgrade, Project $W-353$.

Project Description: There is a radiation monitor and diverter valve associated with each of the generating facilities which discharge to the RPS. The flow is diverted to the RLWS if greater than setpoint radioactivity is detected. The waste diverted to the RLWS is minimized by monitoring the wastewater before it is combined with the other RPS waste streams. Additional screening is performed at the 307 Basins to ensure that TEDF radionuclide acceptance criteria are met prior to discharging to the PS. The diverter stations are being upgraded under Project $W-353$.

Project Status: The hold on project activities has been released and work has resumed. Minor changes to the functional design criteria document are anticipated.

Project Documents

\begin{tabular}{|l|l|}
\hline $\begin{array}{l}\text { Engineering } \\
\text { Studies }\end{array}$ & TBD \\
\hline Design Criteria & $\begin{array}{l}\text { TBD, 1993, Functional Design Criteria for the 300.Area } \\
\text { Diverter Stations Upgrade, Project 94C-EWW-353, } \\
\text { WHC-SD-W353-FDC-001, Revision 0, Westinghouse Hanford } \\
\text { Company, Richland, Washington. }\end{array}$ \\
\hline Design Reports & TBD \\
\hline Permits & TBD \\
\hline Safety Analyses & TBD \\
\hline $\begin{array}{l}\text { Other Relevant } \\
\text { Documents }\end{array}$ & TBD \\
\hline
\end{tabular}


WHC-SD-WM-MAR-003 Rev. 0

APPENDIX B

OTHER LIQUID EFFLUENTS PROJECTS

B-1 
WHC-SD-WM-MAR-003 Rev. 0

This page intentionally left blank. 
Table B-1. 300 Area Process Sewer Piping Replacement, Project L-070.

Project Description: The 300 Area process sewer (PS) collects Tiquid effluents from a Targe number of facilities within the 300 Area. Past practice was to discharge this wastewater to the 300 Area Process Trenches. These trenches receive the untreated wastewater and act as uncovered percolation ditches. This practice, along with the trenches' close proximity to the Columbia River, has lead to public concern.

Project L-070 will provide a new PS system to replace the existing system. The new system will connect each building with a common collection sump at the 300 Area TEDF.

Project Status: Definitive design is approximately $30 \%$ complete.

Project Documents

Engineering

Studies
Bare, K.D., 1991, Engineering Study for 300 Area Process Sewer Rep7acement, Project L-070, WHC-SD-L070-ES-001, Revision 0, ICF Kaiser Hanford Company, Richland, Washington.

CH2M Hi11 and IT Corporation, 1994, Engineering Study of Management Options for 300 Area Noncontact Cooling Water, LL-ES-039, Draft (September 1994), CH2M Hi11, Inc. and IT Corporation, Richland, Washington.

Design Criteria Hayden, K.D., 1991, Functional Design Criteria, 300 Area Process Sewer Piping Upgrade, Project 94L-EWL-070, WHC-SD-L070-FDC-001, Revision 0, Westinghouse Hanford Company, Richland, Washington.

Design Reports

Cline, D.E., 1992, Project L-070, 300 Area Process Sewer System Piping - Conceptual Design Report, WHC-SD-L070-CDR-001, Revision 0, ICF Kaiser Hanford Company, Richland, Washington.

Bare, K.D., 1994, Advanced Conceptual Design Report for 300 Area Process Sewer Piping Upgrade, Project L-070, L070-ACDR, February 1994, ICF Kaiser Hanford Company, Richland, Washington. 
Table B-1. 300 Area Process Sewer Piping Replacement, Project L-070 (cont'd).

\begin{tabular}{|l|l|}
\hline Permits & $\begin{array}{l}\text { TBD, 1994, State Environmental Policy Act (SEPA) } \\
\text { Environmental Check7 ist Forms for Project L-070, 300 Area } \\
\text { Process Sewer, 300 Area, Hanford Site, TBD, Draft (JuTy } \\
\text { 1994), Westinghouse Hanford Company, Richland, } \\
\text { Washington. } \\
\text { Dixon, W.T., 1994, "Notice of Construction for the } \\
\text { Upgrade of the 300 Area Process Sewer System" } \\
\text { (Letter 9455433D to J.E. Rasmussen, U.S. Department of } \\
\text { Energy, Richland Operations Office, Richland, Washington, } \\
\text { Draft), Westinghouse Hanford Company, Richland, } \\
\text { Washington. }\end{array}$ \\
\hline Safety Analyses & $\begin{array}{l}\text { Huang, C.H., 1992, Hazard Classification for the 300 Area } \\
\text { Process Sewer Upgrade, Project L-070, WHC-SD-LO70-HC-001, } \\
\text { Revision O, Westinghouse Hanford Company, Richland, } \\
\text { Washington. }\end{array}$ \\
\hline $\begin{array}{l}\text { Other Relevant } \\
\text { Documents }\end{array}$ & $\begin{array}{l}\text { Arntzen, M.C., 1994, Project Specific Quality Assurance } \\
\text { Plan, Project L-070, 300 Area Process Sewer Piping } \\
\text { Upgrade, WHC-SD-L070-QAPP-001, Revision 1, Westinghouse } \\
\text { Hanford Company, Richland, Washington. }\end{array}$ \\
\hline
\end{tabular}


Table B-2. 307 Basin Maintenance Upgrades, Project W-345.

Project Description: Project $W-345$ is relining the 307 Basins (which are part of the RPS) and converting the system to batch operation. Wastewater which exceeds the discharge limits will be transferred to the 340 Facility.

Project Status: Construction is approximately $40 \%$ complete with final completion scheduled for December 1994.

Project Documents

\begin{tabular}{|l|l|}
\hline $\begin{array}{l}\text { Engineering } \\
\text { Studies }\end{array}$ & TBD \\
\hline Design Criteria & $\begin{array}{l}\text { Berneski, L.D., 1993, Functional Design Criteria } \\
307 \text { Basin Maintenance Upgrades Project 94-EWW-345, } \\
\text { WHC-SD-W345-FDC-001, Revision 0, West inghouse Hanford } \\
\text { Company, Rich7and, Washington. }\end{array}$ \\
\hline Design Reports & TBD \\
\hline Permits & TBD \\
\hline Safety Analyses & TBD \\
\hline $\begin{array}{l}\text { Other Relevant } \\
\text { Documents }\end{array}$ & $\begin{array}{l}\text { Arntzen, M.C., 1994, Project Specific Quality Assurance } \\
\text { P7an, Project W-345, Basin Maintenance Upgrades, } \\
\text { WHC-SD-W345-QAPP-001, Revision 0, Westinghouse Hanford } \\
\text { Company, Rich7and, Washington. }\end{array}$ \\
\hline
\end{tabular}


Table B-3. Richland Treatment Plant Connection, Project V-784.

Project Description: Sanitary sewage collects from various facilities in the 300 Area and is routed through septic tanks to percolation trenches. Negotiations are underway to allow discharge of these wastewaters to the City of Richland's POTW. This project will provide a common sump and piping to connect the 300 Area sanitary sewer to the City of Richland sewer system at the north interceptor.

Project Status: Presently under construction. Forecast completion is December 1994. May be delayed for cultural resources review.

Project Documents

\begin{tabular}{|c|c|}
\hline $\begin{array}{l}\text { Engineering } \\
\text { Studies }\end{array}$ & $\begin{array}{l}\text { Beck, R.W., 1990, } 300 \text { Area Sanitary and Process } \\
\text { Wastewater Study, R.W. Beck and Associates for the City } \\
\text { of Richland, Washington. } \\
\text { SCM Consultants, 1991, } 300 \text { Area Sewage Treatment System } \\
\text { Upgrade Project V-784, SCM Consultants, Inc., Richland, } \\
\text { Washington. }\end{array}$ \\
\hline Design Criteria & $\begin{array}{l}\text { Pursley, D.L., 1992, Functional Design Criteria for } \\
300 \text { Area Sewage Treatment System Upgrades Project V-784, } \\
\text { FDC V-784, Revision } 4 \text { (ECN 165251), Westinghouse Hanford } \\
\text { Company, Richland, Washington. }\end{array}$ \\
\hline Design Reports & TBD \\
\hline Permits & TBD \\
\hline Safety Analyses & $\mathrm{TBD}$ \\
\hline $\begin{array}{l}\text { Other Relevant } \\
\text { Documents }\end{array}$ & $\begin{array}{l}\text { Schultz, J.W., 1992, Project-Specific Quality Assurance } \\
\text { Plan } 300 \text { Area Sanitary Sewer Upgrade Project V-784, } \\
\text { WHC-SD-V784-QAPP-001, Revision 1, Westinghouse Hanford } \\
\text { Company, Richland, Washington. }\end{array}$ \\
\hline
\end{tabular}


Table B-4. 300 Area Ash Pond Replacement and Filter Backwash Pond, Project L-059/V-791H-B.

Project Description: The 300 Area steam plant ash disposal ponds and the water filter plant backwash pond are the receivers of large quantities of liquid effluents which contain nonhazardous solids. Both pond systems employ percolation of the water into the soil column and retention of the solids by the soil. These two projects replace these ponds with Tined sedimentation ponds; effluents will be discharged to the Columbia River. Vehicle access will be provided to facilitate solids removal.

Project Status: Issues regarding the NPDES permit need to be resolved. Project L-059 may possibly be eliminated and the 300 Area steam plant go to burning fuel oil.

Project Documents

\begin{tabular}{|c|c|}
\hline $\begin{array}{l}\text { Engineering } \\
\text { Studies }\end{array}$ & TBD \\
\hline Design Criteria & $\begin{array}{l}\text { Hayden, K.D., 1990, Functional Design Criteria, } 300 \text { Area } \\
\text { Ash Pond Replacement, WHC-SD-LO59-FDC-001, Revision 0, } \\
\text { Westinghouse Hanford Company, Richland, Washington. } \\
\text { Pursley, D.L., 1991, Supplementa7 Design Requirements } \\
\text { Document for Project 91G-EWL-059, WHC-SD-L059-SDRD-001, } \\
\text { Revision 0, Westinghouse Hanford Company, Richland, } \\
\text { Washington. }\end{array}$ \\
\hline Design Reports & $\begin{array}{l}\text { Pursley, D.L., 1990, Conceptual Design Report } 300 \text { Area } \\
\text { Ash Pond Replacement, WHC-SD-L059-CDR-001, Revision 0, } \\
\text { Westinghouse Hanford Company, Richland, Washington. }\end{array}$ \\
\hline Permits & $\begin{array}{l}\text { EPA, 1992, "Draft National Pollutant Discharge } \\
\text { El imination System Permit (No. WA-002592-5)" (Letter to } \\
\text { J.E. Rasmussen, U.S. Department of Energy, Richland } \\
\text { Operations Office, Richland, Washington, December 10, } \\
\text { 1992), U.S. Environmental Protection Agency, Seattle, } \\
\text { Washington. }\end{array}$ \\
\hline Safety Analyses & TBD \\
\hline $\begin{array}{l}\text { Other Relevant } \\
\text { Documents }\end{array}$ & $\begin{array}{l}\text { Pursley, D.L., 1991, Project Specific Quality Assurance } \\
\text { Plan, 90G-GFL-059, 300 Area Ash Pond Replacement, } \\
\text { WHC-SD-L059-QAPP-001, Revision 0, Westinghouse Hanford } \\
\text { Company, Richland, Washington. }\end{array}$ \\
\hline
\end{tabular}


Table B-5. Stormwater Interim Collection and Disposal, Project L-125.

Project Description: This project addresses interim measures and further study of alternatives before implementing a long-term solution. A method of stormwater collection and disposal will be provided by modifying the existing stormwater system north of Apple Street, and provide connections to roof drains. Existing systems will be modified by installing new piping, catch basins, and dry wells.

Project Status: Design is complete. Start of construction is on hold until changes in project scope are resolved.

\section{Project Documents}

\begin{tabular}{|l|l|}
\hline $\begin{array}{l}\text { Engineering } \\
\text { Studies }\end{array}$ & $\begin{array}{l}\text { Hayden, K.D., 1992,300 Area Stormwater Engineering } \\
\text { Study/Project L-125, WHC-SD-L125-ES-001, Revision 0, } \\
\text { ICF Kaiser Hanford Company, Richland, Washington. }\end{array}$ \\
\hline Design Criteria & TBD \\
\hline Design Reports & TBD \\
\hline Permits & TBD \\
\hline Safety Analyses & TBD \\
\hline $\begin{array}{l}\text { Other Relevant } \\
\text { Documents }\end{array}$ & TBD \\
\hline
\end{tabular}

